\title{
Does the quality of voluntary disclosure constrain earnings management in emerging economies? Evidence from Middle Eastern and North African \\ Banks
}

\author{
Rami Salem \\ Accounting and Finance Department \\ University of Central Lancashire, Preston, PR1 2HE, UK; \\ and University of Gharyan, Libya \\ Email: riasalem1@uclan.ac.uk \\ Ernest Ezeani \\ Leicester Castle Business School \\ De Montfort University \\ Gateway House, Leicester, LE1 9BH, UK \\ Email: ernest.ezeani@ dmu.ac.uk
}

\author{
Ali Meftah Gerged \\ Leicester Castle Business School \\ De Montfort University, Gateway House, Leicester, LE1 9BH, UK; \\ and Misurata University, Misurata City, Libya \\ Email: ali.gerged@dmu.ac.uk
}

\section{Muhammad Usman}

Accounting and Finance Department

University of Central Lancashire

PR1 2HE, Preston, UK

Email: musman5@uclan.ac.uk

\section{Rateb Mohammad Alqatamin}

Tafila Technical University,

Division of Accounting, School of Business, Tafila, Jordan

Email: rqatamin@ttu.edu.jo

This paper is cited as:

Salem, R., Ezani, E., Gerged, A. M., Usman, M., Alqatamin, M. A. (2020). 'Does the quality of voluntary disclosure constrain earnings management in emerging economies? Evidence from Middle Eastern and North African Banks', International Journal of Accounting \& Information Management, In Press. 


\begin{abstract}
Purpose

This study examines the influence of the quality of voluntary disclosure (QVD) on earnings management (EM) among a sample of commercial banks in the Middle East and North Africa (MENA) region.

\section{Design/methodology/approach}

Using a sample of 1,060 bank-year observations for the period 2006-2015, we developed a three-dimensional framework to measure the QVD, which considers the quantity, spread and usefulness of the information. Furthermore, this study examines the QVD-EM nexus employing an ordinary least squares (OLS) regression model. This technique is supplemented with conducting an instrumental variable (IV) regression model and a two-stage least squares (2 SLS) model to overcome the potential occurrence of endogeneity problems.
\end{abstract}

\title{
Findings
}

Our findings suggest that QVD is negatively attributed to EM in the context of MENA banks. The findings also confirm that the quality of financial reporting is enhanced by QVD dimensions that were considered in our framework, leading banks to less engagement in EM practices. In contrast, the influence of the quantity dimension (level) of the disclosed information has an insignificant impact on EM, while the spread and usefulness dimensions of voluntary disclosure (VD) are negatively and significantly associated with EM in the region.

\section{Originality/value}

Our study distinctively develops an innovative measurement for QVD using a new multidimensional model. We also bring new evidence on QVD complexity and its impact on EM practice from an under-researched developing context, namely the MENA region.

Keywords Earnings Management, Discretionary Loan Loss Provisions, Quality of Voluntary Disclosure, the MENA region

Paper Type Research

\section{Introduction}

The recent financial crisis has shown the insufficiency of the information disclosed by financial firms and their high level of asymmetric information. For example, the bankruptcies of Lehman Brothers were due to poor financial reporting quality, which misled users, causing them to 
make inaccurate decisions (Jones and Finley, 2011). The failure of these firms has placed additional pressure on professional-standard 'setters' bodies and listed firms to raise the quality of disclosures (Beretta and Bozzolan, 2008). The information asymmetry between managers and owners may occur when managers opportunistically use earnings manipulations to maximize their interests, leading to poor financial reporting quality, which decreases shareholders' confidence in the disclosed information (Cai, Li, and Tang, 2020; Bigus and Häfele, 2018).

Previous EM studies (e.g., Alzoubi, 2016; Katmon and Al Farooque, 2017; Rezaee and Tuo, 2019; Suteja, Gunardi and Mirawati, 2016) suggested that EM is classified into either opportunistic or informative behaviour. In opportunistic behaviour, managers mislead investors to protect their reputation and secure more remuneration. In contrast, from an informative perspective, managers might disclose more relevant information to the investors. Distinguishing between informative practice and opportunistic behaviour is not easy without considering managerial incentives to manipulate earnings figures.

Although a considerable body of prior studies examined the impact of voluntary disclosure (VD) on EM (Katmon and Al Farooque, 2017; Rezaee and Tuo, 2019; Suteja et al., 2016), there is still an existing gap in the literature related to the measurement of VD. When examining the relationship between VD and EM, two VD measurement methods have been used. The first method used the level and quantity of the disclosed information to measure VD. However, this method neglects some important dimensions, such as the spread and usefulness of VD that distinguish the disclosed information. The second method uses subjective analyst disclosure quality rankings (Francis, Nanda and Olsson, 2008; Husted and De Sousa-Filho, 2018; Muttakin, Khan and Azim, 2015; Sun and Rath, 2010). Such indices may not be widely applicable for availability and transparency reasons (Chatterji et al., 2009).

The motivations of this study are two-fold. Firstly, we go beyond previous studies that ignore the effect of spread and usefulness dimensions in measuring QVD (Alotaibi and Hussainey, 2016; Alturki, 2014; Francis, Nanda and Olsson, 2008; Habbash, Hussainey, and Awad, 2016; Lobo and Zhou, 2001; Muttakin et al., 2015). Therefore, we contribute to the existing body of literature by developing a comprehensive framework that considers three dimensions (i.e., quantity, spread and usefulness) to captures the QVD and examine the QVD-EM nexus. Secondly, to date, a study examining the impact of VD on EM in the banking sector is virtually non-existent. The extant literature of the influence of voluntary disclosure on earnings management provides inconsistent outcomes. For instance, Katmon and Al Farooque (2017) found that VD is negatively associated with EM. Conversely, Prior et al. (2008) have reported 
that VD is positively associated with EM. This paper, therefore, addresses this gap by examining the VD-EM nexus using a dataset that has been manually collected from commercial banks operating in the MENA region. This also brings a new perspective leading to a unique contribution to QVD and EM literature.

This paper investigates the extent to which the QVD and EM are statistically and theoretically correlated. Theoretically, managers may voluntarily disclose high-quality voluntary information to mitigate information asymmetry further to signalling their superior performance to those interested in their information (Miller, 2002). Hypothetically, it is expected that managers who voluntarily release high-quality information are unlikely to engage in earnings manipulation. Since high information asymmetry is likely to result in EM practice, the QVD is assumed to mitigate the information gap between agent and principle. Thus, QVD is considered as a vital instrument to monitor executive' opportunistic behaviour and constrain the incidence of EM practice (Bushman and Smith, 2001). Furthermore, the magnitude of EM is less likely to be correlated to the level of VD, which implies a compensatory relationship, meaning that firms with poor quality disclosures might attempt to gain legitimacy by disseminating more information voluntarily to compensate stakeholders for the inadequacy of the disclosed information (Rodríguez-Ariza et al., 2017).

In our study, we use a sample of 106 commercial banks listed in 17 MENA stock exchanges covering a ten year period. Our study employed loan loss provisions (LLP), which is widely used in the banking industry as the main tool for managing EM (Kwak et al., 2009; Leventis et al., 2012). The extent of LLP for each sample firm-year was estimated using Kanagaretnam et al. (2004) model. Our empirical findings suggested that banks that provide high QVD appeared to be less engaged in EM. Additionally, we found no evidence on the association between the quantity (level) of VD and EM in the MENA region.

Our study makes the following contributions. First, prior VD-to-EM studies were confined to examining the relationship between the level of VD and EM (i.e., Katmon and Al Farooque, 2017; Rezaee and Tuo, 2019; Suteja et al., 2016). Our study, therefore, extends the body of previous literature by considering the collective effect of VD quality and quantity on the engagement in earnings manipulation in the banking sector. To achieve this objective, we develop a three-dimensional framework to measure the QVD. This framework takes into consideration the quantity, spread and usefulness of the information disclosed voluntarily, which is regarded as the most comprehensive proxy for disclosure quality. This allows for indepth descriptions of the patterns and the nature of the disclosed information. 
Second, while previous studies have documented that the information asymmetry levels among non-financial institutions are very high (Alotaibi and Hussainey, 2016; Mersni and Othman, 2016; Moumen et al., 2016), there is still an insufficient substantiation on the effect of VD on EM in the banking sector. Thus, we fill this gap by using data from commercial banks operating in 17 MENA countries. Also, our paper is, to the best of our knowledge, the first study to offer springboard of the relation between QVD and EM in the financial services sector. Third, we also extend the recent work of Alotaibi and Hussainey (2016), Mersni and Othman (2016), and Moumen et al. (2016) on earnings manipulation and voluntary disclosure by providing new evidence about the effect of QVD on EM in emerging economy context. Our findings are expected to assist regulators, policy-makers, market participants, and academics in appreciating the function and the importance of QVD dimensions in mitigating EM.

The rest of the paper is organised as follows: Section two develops the theoretical framework and literature review, while Section three describes the research method used. Next, in the finding section, the main results, additional analysis, and robustness tests are outlined. The final section presents the main discussion, implications, and limitations.

\section{Literature Review and Hypotheses Development}

Prior literature considered EM as a form of agency cost since directors engage in opportunistic behaviours by providing inaccurate information that does not reflect the firm's economic reality (e.g., Kwak et al., 2009; Leventis et al., 2012; Othman and Mersni, 2014). The issue of information asymmetry allows managers to manipulate earnings to gain personal benefits since their compensation might directly depend on the reported results. It might also increase job security at shareholder's expense (Alzoubi, 2016; Chong et al., 2012; Darjezi, 2016). In the banking industry, considerable discussion and criticism concluded that earnings manipulation and executive compensation are some of the main reasons for their financial crisis from 2007 to 2008 (Alhadab and Al-Own, 2019).

In contrast, VD transcends mandatory disclosure requirements and represents management's free choices to provide relevant information in their annual report to enable users to make informed decisions (Meek, Roberts, and Gray, 1995, p. 555). Two perspectives have been suggested by previous research to describe the impact of QVD on EM, namely, opportunistic and long-term perspectives. The long-term perspective enables firms to reduce information asymmetry and improve financial decisions in capital markets by signalling high-quality 
information (Uyar, Kilic, and Bayyurt, 2013). Given the proposition of a positive correlation between EM and information asymmetry, signalling theory assumes that information asymmetry is mitigated by disclosing high-quality information voluntarily (Harun et al., 2020). Managers may avoid the issue of asymmetric information through voluntarily signalling credible and relevant (high-quality) information to the market (Watts and Zimmerman 1978). In this regard, loan loss provision (LLP) is utilised by bank' managers as a signalling approach to convey a signal of conservatism and confidence about their financial strength (Ahmed et al., 1999). Gray (2004), for example, reported that managers of highly performed and financially stable firms have a desire to distinguish themselves from poorly performed firms by extending (signals) high- quality information voluntarily to communicate successfully.

The legitimacy theory, on the other hand, argues that firms disguise their opportunistic behaviour through disclosing information voluntarily (Li et al., 2012; Parvin et al., 2020). Li, Mangena, \& Pike (2012) argued that managers might voluntarily reveal information to shade their opportunistic behaviour and to protect themselves against any possible reaction from stockholders. The view of legitimacy theory proposes that "individual actions are substantially related to their self-interest, and respectively individuals may rise their wealth by engaging in EM practices" (Jensen \& Meckling, 1976). Consequently, this perspective suggests a substitutive association between EM and QVD, in the sense that VD is used as a legitimate mechanism to compensate for poor financial reporting quality (Francis et al., 2008; MartínezFerrero et al., 2015).

Prior studies examined the effect of VD on EM, although their results have been proven to be inconsistent. For example, Rezaee and Tuo (2019), Katmon and Al Farooque (2017) and Alzoubi (2016) found that VD is negatively associated with EM. Conversely, Kasznik (1999), Patten and Trompeter (2003), Prior et al. (2008) have reported contradictory evidence, as they found that VD is positively correlated with EM.

Specifically, Rezaee and Tuo (2019), investigated the effect of the quality and quantity of governance, social and environmental disclosure on earnings management in the context of culture and corporate ethical value. It was found that the quantity (level) of sustainability disclosure in the USA non-financial firms is negatively correlated with earnings manipulations. They also found that the quality of sustainability disclosure strengthens the negative association between the sustainability level of disclosure and earnings management. In the UK context, however, Katmon and Al Farooque (2017), examined the influence of internal corporate 
governance on the quality of disclosed information and earnings manipulations using three different indices to capture the quality of disclosure. These indices are Forward-Looking Score, Investor Relation Magazine Award and the analyst forecast accuracy. They conclude that all three proxies of disclosure quality have significantly and negatively influenced corporate engagement in earnings management, whereas corporate governance mechanisms seem to have an insignificant influence on earnings manipulations in the UK setting. In the Middle Eastern countries, Alzoubi (2016) investigates the relationship between internal corporate governance mechanism and earnings management practices among 62 companies listed on the Amman Stock Exchange. The study's findings reveal that managerial ownership, external blockholder, institutional ownership, foreign ownership and family ownership have an inverse relationship with EM.

Also, Alzoubi (2016), has investigated the impact of the quality of disclosure on earnings manipulation among non-financial companies registered in the Jordanian Stack Exchange using the disclosure index of Beattie et al. (2004). The study points out that the quantity of disclosure (level) can restrain earnings manipulation, which in turn expected to improve the quality of annual reports in the Jordanian context.

On the contrary, Prior et al. (2008) and Patten and Trompeter (2003), tested the association between earnings manipulation and corporate social responsibility (CSR) and environmental disclosure among non-financial firms over 26 different developed countries. These studies utilised a disclosure index to capture the level of disclosed information and found a positive relationship between earnings manipulation and corporate disclosure, which in turn negatively impact the companies' financial performance. From a managerial perspective, this empirical evidence suggests that VD seemed to be employed by managers as a method to reduce firm's exposure, political and social pressures (Patten and Trompeter, 2003); thus, managers might attempt to opportunistically disclose more information voluntarily to cover any misconduct such as earnings manipulation (Ullah et al., 2019). In the same manner, a study conducted by Kasznik (1999) aims to investigate the effect of information disclosed voluntarily on EM among 366 US-listed companies during the period 1987 - 1991. The study's finding reveals that voluntary disclosure is positively and significantly affected EM practices. This result suggests that directors who are overstated earnings are very likely to shift announced earnings aiming to meet their anticipation. Similarly, several studies have investigated the relationship between the quantity of CSR and earnings manipulation on non-financial sectors (Muttakin et al., 2015; Prior et al., 2008; Patten and Trompeter, 2003). Their findings show that the level of 
CSR and EM practices are positively and significantly related. These studies confirm that managers who tend to publish high level of CSR are motived to practice EM.

Prior studies appeared to have a number of limitations. First, the majority of previous VD-toEM studies were limited to examining the effect of the level of information provided voluntarily on EM practices without considering the spread and usefulness of the information disclosed. In this regard, Beretta \& Bozzolan (2008) state that the level of VD is not the only approach of measuring the quality of disclosed information as considering other matters such as the type and variety of the disclosed items became a more dominant proxy for the quality of VD. In addition, Botosan (2004) asserted that the notion of QVD should be consistent with the conceptual framework of IFRS. This will find an acknowledged explanation of disclosure quality, in turn, could increase the quality of disclosed information and then enhancing decisions making processes (IFRS 2010). Second, a previous study focusing on examining the QVD-EM nexus in the banking sector is virtually non-existent. Third, the vast majority of QVD-to-EM studies have been devoted to investigating the context of developed economies (e.g., Francis, Nanda and Olsson, 2008; Husted and De Sousa-Filho, 2018; Lobo and Zhou, 2001) with a little attention has been paid to bringing up contextual insights from developing economies settings. Our study contributes to the ongoing debate on the possible effects of QVD on EM in several ways. First, we extend the body of existing literature by developing a multidimensional framework to measure the quality of VD. Second, we add to the literature by considering the impact of the quality along with the quantity of VD on EM. Third, our study addresses the dearth in prior studies by examining the QVD-EM nexus in the banking sector. Finally, our research paper brings up new empirical evidence on the QVD-EM link from an under-research context, namely the MENA region, yet of a major economic and political importance to the global economy.

Managers of institutions operate in the MENA region implement social accountability approach, which is associated with anti-manipulative behaviour, enhance the transparency of the disclosed information. Social accountability is considered as the institutionalised mechanism of control, which impacts both firm and individuals' attitudes (Lassoued, Attia, \& Sassi, 2018). Similarly, Brusca et al. (2016) indicated that directors of firms should disclose valuable information to be accountable to the society and enhancing their reputation in response to any potential outside stress performed by regulatory bodies. Since the full disclosure is linked to social accountability, society has the right to receive high-quality information regarding the company's operations. In the same manner, Haniffa and Hudaib (2002), conclude 
that high-quality disclosure could assist directors in performing their accountability to society and helping stakeholders to take an accurate decision.

Signalling theory argues that directors are motivated to reveal extensive information since accounting information is considered to be a signal to the capital market (Spence, 1973). Furthermore, signalling theory assumes that managers in the banking sector are very likely to used loan loss provision (LLP) as a signal instrument to transfer bank's particular information to stakeholders, and therefore, send positive signals to stakeholders regarding their financial strength (Ahmed et al., 1999; Darjezi 2016). Based on the signalling theory, bank managers are tended to raise LLP to signal valuable information regarding their upcoming earnings, consequently, enhancing shareholders' confidence about the bank's earnings (Ahmed and Courtis 1999). Banks with a low level of performance are expected to be involved in EM practices through decreasing LLP to increase the bank's earnings. This approach could minimize the opportunity of being reviewed by regulatory agencies aiming to maximums management compensation. In this regard, Alhadab and Al-Own (2019) conducted a study that aims at examining the impact of equity incentives on earnings management using loan loss provisions (LLP) among 39 European banks. Their results show that managers of European banks widely use income-increasing earnings management by discretionary loan loss provisions, and that is partly motivated by the compensations of manager's. The acceptably explanation of this argument is that managers are willing to send a signal that includes false information related to decreased or increased LLP to meet their expectations (Ashraf et al., 2014).

Besides, signalling theory suggests that accurate, complete, and reliable VD decreases information asymmetry between internal and external users (Katmon and Al Farooque, 2017). Since managers could reduce the asymmetric information by releasing high-quality information to the market (Miller, 2002; Watts and Zimmerman, 1990), it is expected that companies which provide QVD are less likely to be involved in earnings manipulation. Consequently, based on the results of previous studies that indicate a possibility of a negative association between QVD and EM (e.g., Rezaee and Tuo 2019; Katmon and Al Farooque 2017; and Alzoubi 2016; Lobo and Zhou 2001) and in the light of several of theoretical arguments primarily stemmed from Legitimacy theory and signalling theory, this study proposes the following hypothesis.

$\mathbf{H}_{1}$ : Ceteris paribus, there is a statistically significant and negative relationship between the QVD and EM practices in the context of MENA banks. 


\section{Data and methodology}

The dataset used in our study was collected from banks listed in MENA stock exchanges and covered ten years period spans from 2006 to 2015 to ensure a consistent and adequate number of observations. The study started in 2006 due to the adoption of Basel II in 2005 across banks operate in MENA countries (Elamer et al., 2020). The selection of commercial banks in MENA countries is of a significance stemming from their considerable financial influence in the context of an emerging economy at large (Bourgain et al., 2012). For example, according to their credit levels and banking assets, MENA countries have been ranked second in terms of banking sector development (Ben Rejeb Attia et al., 2019). Similarly, banks operate in the MENA region have embraced Basel ii regulations that attempt to enhance the transparency and credibility of disclosed information Likewise, a series of reforms have been embraced by policy-makers in the majority of MENA countries to build a solid, institutional and legal framework which in turn attracts external fund and boost investors' rights protection (Buallay et al., 2020). More specifically, enhancing the supervision, regulation and increasing transparency of banks are considered as a sample of the reforms that banks should undertake through imposing provisions for the information disclosed and implementing high-quality corporate governance mechanism that is in line with the international standards (Elfeituri, 2018). In light of these characteristics, the banking system across MENA countries is heavily required by the adopted liberalization policies to improve the quality of reported financial and non-financial information in corporate annual reports (Kamla, 2007).

Our data have been carefully collected from annual reports, the Orbis Bank Focus database, and the OSIRIS database to avoid any data unavailability and inconsistencies. The whole population of 149 listed commercial banks in MENA countries is used as the initial sample size. To ensure the generalisation of the study findings, we excluded those banks characterised with incomplete data, government banks, cooperative banks, Islamic banks as they have different regulatory requirements compared to commercial banks. We also filtered the sample by covering the period of Pre- and post-banking crisis and the adoption of Basel II in 2005 across banks operate in MENA countries (Elamer et al., 2020). Thus, after applying the adopted sampling criteria, the final sample of our study is ended up with 106 commercial banks selected from 17 MENA countries with a total number of 1,060 bank-year observations. Table I presents the banks' specifications by country.

INSERT TABLE (I) 


\subsection{Measurement of EM}

Following the prior literature (e.g., Abdelsalam and El-Komi, 2016; Othman and Mersni, 2014; Elleuch and Taktak, 2015), we measured EM based on loan loss provision using Kanagaretnam et al. (2004) model. This model is a sector-specific approach and considered as the most reliable and robust approach in the banking industry that enables us to distinguish between nondiscretionary and discretionary accruals (Abdelsalam et al., 2016). Unlike other EM models, Kanagaretnam et al. (2004) model utilise LLP that represents the largest portion of accruals in the banking industry (Lobo \& Zhou, 2001) and plays a major role in the manager's decision to manipulate earnings (Beaver \& Engel, 1996).

Our study employed the following cross-sectional equation in the estimation of the discretionary part of LLPs:

$$
\text { LL-Psit }=\beta_{0}+\beta_{1} \text { NP-Lit-1 }+\beta_{2} \Delta \text { NP-Lit }+\beta_{3} \Delta \text { T- } \mathrm{L}_{\mathrm{it}}+\varepsilon_{\mathrm{it}}
$$

This model consists of a non-discretionary component of loan loss provision (ND_LLP) ${ }^{1}$. The ND_LLP can't be directly achieved. However, it is obtained via the changes in the bank business condition. Following Kanagaretnam et al. (2004) and Kwak et al. (2009), we estimated ND_LLP through enclosing several variables that reveal the level of loan loss portfolios such as non-performing loans, total loans, and changes in non-performing loans. Therefore, ND_LLP is estimated by utilising the equation (A) and evaluation gained via its predicted ( $\beta_{0}$ $\beta_{1} \beta_{2} \beta_{3}$ ) coefficients (see equation B). The discretionary loan loss provision (D_LLP) relies on the predicted LLP estimation error obtained through the residual of equation (A). The final estimation process stage is to calculate the D_LLP through the difference between the estimated ND_LLP and D_LLP (See equation C). In line with previous studies (i.e., Abdelsalam and El-Komi, 2016; Grougiou et al., 2014; Jackson., 2018), we used D_LLP as a proxy of earnings management as it is directly linked to managers decisions in manipulating earnings through underestimating or over-estimating LLP.

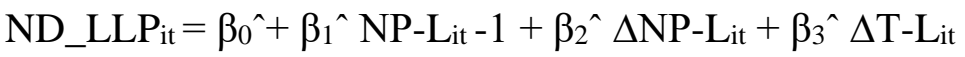

$$
\begin{aligned}
& \text { D_LLP } i t=L-L P i t ~-N D \_L L P i t .
\end{aligned}
$$

where:

\footnotetext{
${ }^{1}$ For further information refer to Kanagaretnam, K., Lobo, G. J., \& Mathieu, R. (2004). Earnings management to reduce earnings variability: Evidence from bank loan loss provisions. Review of Accounting and Finance, 3(1), pp.128-148.
} 
LL-Psit: is calculated as total loan loss provisions for bank $\mathrm{i}$ at year $\mathrm{t}$, divided by beginning total loans, NP-Lit-1: is the beginning balance of the non-performing loans for bank $i$ at year $t$ divided by the beginning, total loans, $\triangle \mathrm{NP}-\mathrm{Lit}_{\mathrm{it}}$ is calculated as the change in the value of non-performing loans for bank $i$ at year $t$, divided by the beginning, total loans, $\Delta \mathrm{T}$-Lit: is measured as the change in the value of total loans for bank $\mathrm{i}$ at year $\mathrm{t}$, divided by the beginning, total loans, ND_LLP ${ }_{\text {it: }}$ is the non-discretionary loan loss provisions for bank $\mathrm{i}$ at year $\mathrm{t}, \mathrm{D} \_L L P$ it: is the discretionary loan loss provisions for bank $i$ at the year $t$.

\subsection{Measurement of $Q V D$}

In the initial stages of conducting the current study, we adapted the disclosure framework of Beattie et al. (2004), which consists of the disclosure quantity and the spread. We then expanded this framework to capture three disclosure dimensions, which are (i) quantity (how much and what information is voluntarily reported), (ii) information disclosure spread (concentration and coverage of information), and finally, (iii) the usefulness of the disclosed information. Our expanded framework is based on these three dimensions and provides evidence regarding banks' QVD, which allows both qualitative and quantitative features of the disclosed information to be captured. The following sections explain how each dimension of the QVD framework is measured.

\subsubsection{Quantity Dimension}

This dimension represents the VD amount that is adjusted by business size. Previous studies have suggested that disclosure levels are affected by business complexity and size (e.g., Beretta and Bozzolan, 2008; Platonova, Asutay, Dixon, and Mohammad, 2018; Rezaee, and Tuo, 2019). Since our sample covers one industrial type (conventional banks), the quantity dimension (ST-R_Q) is measured by considering the variation in size of the banks to provide an effective evaluation of quantity VD. To capture the quantity of VD in annual reports, content analysis was applied. We constructed a checklist consisting of 88 items (see Appendix A). The selection and development of the categories for the classification of content is an important element of conducting a content analysis technique. Particularly, our study followed Menicucci (2013) and Maali et al. (2006) to develop a comprehensive checklist that contains items relevant to MENA banks. The number of words was employed to measure ST-R_Q in the current study. We used the relative number of words adjusted by bank size to capture the STR_Q dimension since this external factor has been found to affect the level of disclosure. The standardised OLS estimation of the number of words (how much) on bank size was employed as the quantity dimension proxies. Following Beretta and Bozzolan, (2008), we obtained the 
R_Q $\mathrm{Q}_{\text {it }}$ by excluding the residual (estimated disclosure) from the actual total frequency of disclosed items. Then the maximum and minimum value of $\mathrm{R}_{-} \mathrm{Q}_{\text {it }}$ form the overall sample are used to achieve the quantity dimension finally. We adopted the following standardised formula ${ }^{2}$ :

$$
\mathbf{S T}_{-} \mathbf{R}_{-} \mathbf{Q}_{i t}=1-\frac{\mathbf{M a x}_{-} \mathbf{R}_{-} \mathbf{Q}_{i t}-\mathbf{R}_{-} \mathbf{Q}_{i t}}{\text { Max_-R_- }_{i t}-\operatorname{Min} \mathbf{R}_{-} \mathbf{Q}_{i t}}
$$

Where:

ST_R_Qit $=$ standardised relative quantity index for the bank $\mathrm{i}$ at year $\mathrm{t}$.

R_Q $\mathrm{Q}_{\mathrm{it}}=$ is the relative quantity index, which is the residual for the banks $i$ at year $t$ that obtained after controlling the size of the bank.

\subsubsection{The Spread Dimension}

The spread of VD is the second dimension used in this study since it helps to evaluate whether the voluntarily disclosed information meets the needs of various stakeholders. The functions of VD dispersion (DI_S) and VD coverage (CO) were used to determine the dimension of spread. We measured $\mathrm{CO}$ as the proportion of VD items reported by the banks in the annual reports from the total number of VD items contained in the index. The range of $\mathrm{CO}$ is between 1 and 0 . The highest value (1) is assigned if each of the topics (sub-topics) in the checklist is disclosed in the bank's annual report, whereas the lowest value (0) is assigned with nondisclosed topics. The following equation is used in measuring $\mathrm{CO}$ :

$$
\mathrm{CO}_{\mathrm{it}}=\frac{1}{\mathrm{st}} \sum_{j=1}^{s} \mathrm{IN} \_\mathrm{F}
$$

Where, IN_F $=1$ if bank $i$ provides information in the annual report about item $j$ and otherwise 0 , and $s$ is the number of subcategories. We used DI_S as an indication of disclosed items' concentration within the disclosure index. We also used the frequency of items disclosed from index A to obtain the concentration of disclosed items. This technique is adopted to examine whether bank managers focus (giving signals) on specific items or provide a variety of information about all items involved in the index. The following is the DI_S equation:

$$
\text { DI_S } \mathrm{Sit}_{\mathrm{it}}=1-\sum_{j=1}^{n} \mathrm{P}-\mathrm{j}^{2}
$$

Where $\mathrm{P}-\mathrm{j}=$ proportion of disclosed item $i$ measured by the item disclosure frequency in category $j$. In the current study, 0 is assigned as a value of DI_S if all VD words fall into one

\footnotetext{
2 Further information about the measurement of quantity and spread dimensions can be found in Beretta, S., \& Bozzolan, S. (2008). Quality versus quantity: the case of forward-looking disclosure. Journal of Accounting, Auditing \& Finance, 23(3), 333-376.
} 
category, and a higher value is assigned when VD words are spread between categories. The quality of disclosure increases in line with the DI_S index value. Larger CO and DI_S indices indicate a higher information spread (SP_R). Thus, the average of DI_S and CO is used as a proxy for the spread dimension:

$$
\text { SP_Rit }=\frac{1}{2}\left(\mathrm{DI} \_\mathrm{Sit}+\mathrm{CO} \text { it }\right)
$$

\subsubsection{The Dimension of Usefulness}

Using the five fundamental qualitative characteristics of IFRS (2010): "comparability" "relevance" "understandability", "faithful representation", and "timeliness", we have innovatively developed an index of disclosed items to measure VD usefulness. To evaluate the scores of each item, we employed rating scales with five points for all qualitative characteristics except timeliness, which was measured by using the natural logarithm of the number of days between the year-end and the auditor's signature on the reported post-year-end calculation (see Appendix B). In line with Alotaibi and Hussainey (2016), we measured usefulness by using the weighted method as follows:

US_EF $=\frac{1}{5}$ (Comparability + Relevance + Understandability + Faithfulness + Timeliness $)$ Finally, the average of the three dimensions provides the quality of the information disclosed voluntarily. The QVD is defined as follows:

$$
\mathrm{QVD}=\frac{1}{3}\left(\mathrm{ST}_{-} \mathrm{R}_{-} \mathrm{Q}+S P_{-} R+U S_{-} E F\right)
$$

Several steps were taken to ensure the reliability and validity of QVD measurement. Firstly, to improve validity, we carefully developed our checklist based on previous studies. Secondly, the initial index was independently reviewed by four experts in the area of QVD, who offered their opinion on the ambiguities found in the review. To improve the reliability of our measurement, firstly, we used multiple coders to score the research instrument (Alotaibi and Hussainey 2016). We, secondly, discussed and resolved the discrepancies and any emerging problems accordingly. Thirdly, we used a sample of annual reports to compare the disclosure coding scores among coders. Fourthly, to validate the QVD model, we verified whether QVD is related to market reactions. Previous studies documented that the market reacts positively to QVD (Cahan et al., 2016; Nekhili et al., 2017), which signals the high quality of information disclosed by banks. Therefore, the market-based value (MBV) was employed to indicate the 
market reaction; it is calculated using the aggregate of both earnings per share (EPS) and Tobin's $\mathrm{Q}^{3}$.

The untabulated findings of the panel data regression illustrate that QVD has a positive and significant association with MBV at 1 percent level, and the coefficient is equal to 0.1257 . This finding suggests that a VD of high-quality information is more likely to help market participants to predict banks' earnings in the subsequent year. Thus, we provide experimental evidence to support the validity of the developed framework.

\section{Empirical model}

Following prior studies, we used several control variables that may affect EM and QVD (see, e.g., Abdelsalam and El-Komi, 2016; Alotaibi and Hussainey 2016; Moumen et al., 2016; Nekhili et al., 2017). In particular, the following variables are considered: bank size, growth, leverage, profitability, liquidity, credit risk and capital adequacy ratio, external financing (LD), independent board of directors (I_BD), board size (B_Z), board expertise (BD_EX), duality (D_U), board gender diversity (B_GD), board meeting (B_M), independence of audit committee (I_AC), size of the audit committee (A_CZ), audit committee meetings (A_CM), the expertise of audit committee members (A_CEX), external audit (Big_4), gender diversity of audit committee members (A_CG), managerial ownership (M_OS), and block-holders (B_H). Following Abdelsalam and El-Komi (2016), a dummy variable is used to control country-specific effects. It is related to those countries that experienced political issues during the years from 2011 to 2015. A value of 1 is assigned if a bank is based in Tunisia, Egypt, Yemen, Syria, or Iraq and zero otherwise. Additionally, we used a dummy variable to control for the difference in economic environments among MENA countries. A value of 1 is given for Gulf Cooperation Council (GCC) countries and zero otherwise. We used the following model (1) to examine the effect of QVD on $\mathrm{EM}^{4}$ :

$E M_{-} L L P_{i t}=f\left(\mathrm{QVD}_{i t} ;\right.$ Corporate Governance $_{i t} ;$ Bank characteristics $_{\mathrm{it}}+$ country effects $\left._{\mathrm{it}}\right)$

Following prior studies (Katmon and Al Farooque, 2017; Rezaee and Tuo, 2019), we utilised the Chow test to compare between panel and pool regressions. The untabulated result shows that $\mathrm{F}$ statistics is highly significant at $1 \%$ level, confirming the suitability of panel data

\footnotetext{
3 Following prior studies, Tobin's Q is measured as the market to book value of equity, whereas EPS is calculated as net income scaled by the total number of outstanding ordinary shares (Cahan et al., 2016; Nekhili et al., 2017).

4 The Model Variables' Definitions and Measurements are presented in Appendix (C)
} 
regression. In the second phase, we used the Hausman specification test to compare between random and fixed effects regression, and we found the random effect is the most suitable for our sample as $\mathrm{P}$ value was insignificant $(\mathrm{P}=0.1109)$.

\section{Results and Discussion}

From the descriptive statistics presented in Table II, the QVD standard deviation and mean values for the entire sample are 0.0530 and 0.5774 , respectively and are consistent with those results reported by Michelon et al. (2015) and Lim et al. (2017), that suggest an averages value of QVD varies between 56\% and 57\% among the UK and Australian listed firms, respectively. However, this finding is higher than those of Ghosh (2018), who reported that the level of disclosure is about $20 \%$ among MENA banks during the period 2000-2012. This discrepancy can be justified by the variance in the technique utilized to measure the disclosed information and to the investigated period as most MENA banks started adopting IFRS in post-2006 (Elnahass et al., 2014). The mean value of EM_LLPs is 0.1115 , with a high degree of dispersion. Nevertheless, the findings show that the EM_LLP value across MENA banks is higher compared to those of Abdelsalam and El-Komi (2016), who reported 0.002 to be the average value of EM among MENA banks. The observed variation in the results of both studies may be attributable to the EM measurement differences. Unlike Abdelsalam and El-Komi (2016), we used the absolute EM value instead of using signed discretionary accrual value since the objective of our study is to examine the extent of EM and not the direction.

The correlation among the independent variables is reported in Table III. The standard errors are likely to be inflated by the collinearity issue between the Big 4 and A_CEX, which may cause some variables to be statistically insignificant. In line with Gujarati and Porter (2009), A_CEX was omitted due to the high level of correlation and less significant relationship with the EM proxy. The correlation coefficients of other explanatory variables are below the conventional threshold, meaning that the issue of multicollinearity among our study variables does not exist.

\subsection{Multivariate Analysis}

The main findings of our study are reported in Table IV and show a negative association between EM_LLP and QVD, which is in line with those of some previous studies (Iatridis and Kadorinis, 2009; Lobo and Zhou, 2001; Sanjaya and Young, 2012; Tariverdi et al., 2012). Our result suggests that banks with high QVD are more likely to mitigate EM practices. This 
evidence supports the contention that the increased level of transparency reduces asymmetric information expectations among stakeholders. This result supports the long-term perspective, suggesting that high QVD is provided by banks to minimise information asymmetry and boost owners' confidence regarding firms' future and current performance (Akisik and Gal, 2011). Furthermore, our outcomes are consistent with the perspective of signalling theory, suggesting that banks QVD mitigates information asymmetry by signalling superior performance to the information users (Prado-Lorenzo et al., 2008; Miller 2002). Thus, the current study accepts $\mathbf{H}_{1}$ that QVD has a negative impact on EM.

In respect to MENA countries, our results appear to be well substantiated by those described by Ben Rejeb Attia et al. (2019) and Gerged et al. (2020), signifying that involving in any type of unethical practice such as EM may lead to imposing penalization by stakeholders, and therefore, bank directors are very likely to provide high QVD to mitigate any potential fine and to be recognised as ethically accountable. Noticeably, the quality of disclosure has spectacularly raised which could be attributed to the governments' role in most of MENA region to improve disclosure quality and due to the series of reforms adopted by policy-makers to set up a legal and institutional framework aiming to boost investor protection and attracting foreign direct investments (Kamla, 2007). Most importantly, banks in MENA countries are required to implement corporate governance codes to be in line with the internationally recognized standards. Therefore, implementing reforms and imposing provisions for the disclosure have dramatically improved supervision, regulation and transparency (Turk-Ariss, 2009). In light of these characteristics, banks operate in the MENA region seem to be torn by the growing demand to promote disclosure quality, which is imposed by liberalization policy (Kamla, 2007).

This outcome provides important implications for regulators and standard-setters, enabling them to continually improve the guidelines and framework to assist banks in providing high QVD. It also offers significant implications for bank managers in the MENA region by paying more attention to the quality of voluntary disclosure dimensions.

\section{INSERT TABLE (II)}

\section{INSERT TABLE (III)}

Regarding control variables, we found a negative association between EM and the Big 4 auditors, indicating that Big 4 audit firms are effective in constraining the occurrence of EM 
practices of banks in MENA countries. This result corroborates the findings of Kanagaretnam et al. (2010) and Lin and Hwang (2010), who confirmed the negative impact of contracting with a Big 4 auditing firm on the engagement in EM. Furthermore, the B_H has a negative relationship with EM at the $1 \%$ level, indicating that banks with a higher B_H ratio found to have a lower level of EM. The result is in line with prior studies, which have shown that B_H with at least a 5\% equity stake can play a key role in the mitigation of managerial opportunism (Shleifer and Vishny, 1997). Consistent with Ding and Zhang (2007) and Klein (2002), we found that B_H is negatively related to EM.

Concerning bank characteristics, bank size (BSIZE) has a negative relation with EM. Previous studies (Hadani et al., 2011; Kim et al., 2012; Lin and Shen, 2015; Scholtens and Kang, 2013) found similar findings as large-sized banks are less likely to manipulate their earnings figures as compared with smaller banks. This is due to an increase in the monitoring mechanism employed by regulators and their focus on potential EM-related issues (Kim et al., 2012). Also, the coefficients of growth and L_IQ have a negative effect on EM, implying that due to increased monitoring, banks with higher growth opportunities and greater liquidity are unlikely to engage in EM (Cornett et al., 2009). Furthermore, our results reveal that the external financing proxy (L-D) is negatively associated with EM, suggesting that managers manipulate earnings to attract external funds. They engage in EM by reporting low LLPs, thus decreasing the perceived risk and increasing the reported earnings (Othman and Mersni 2014). In contrast, the regression results reveal that none of the board characteristic variables, leverage, profitability, credit risk, and capital adequacy ratio, have any influence on banks' involvement in EM in the MENA region.

\section{INSERT TABLE (IV)}

\section{Additional analysis}

We check the robustness of the primary findings by employing the quantity of voluntary disclosure as an alternative proxy for QVD to examine whether EM is reduced or enhanced by using the new proxy. We argue that, despite the inseparable nature of the quantity and the quality of voluntary disclosure, the mere quantity evaluation of voluntary disclosure activities is unlikely to improve market decisions. Following prior studies, we used content analysis to measure the quantity of voluntary disclosure (QD) and repeated the main analysis (Belgacem and Omri, 2015; Haniffa and Cooke, 2005). The findings of the additional analysis are reported in Table V. We found that the quantity of disclosure (QD) has an insignificant effect on EM 
compared to QVD, which has a significant and negative influence on EM. Our findings support the main hypothesis, showing that it is the quality rather than the QD, which is very likely to enhance the financial reporting quality by reducing EM.

\section{INSERT TABLE (V)}

Furthermore, to achieve the confidence of our analysis that the main outcome does signify the effect of QVD on EM practice, we examine whether the influence of QVD on EM differs between the high QVD and low QVD banks. Using the median value of QVD, we split the sample into two sub-sets. The first sub-set consists of "high QVD banks," whose QVD is above the median value, and the second sub-set is identified as "low QVD banks" with QVD below the median value. Table VI shows that banks associated with high QVD are less likely to engage in EM, although EM is insignificantly related to QVD in low-QVD banks in the MENA region. This means that high-QVD banks are less likely to manipulate their earnings figures as compared with low-QVD banks (Lin and Shen, 2015; Scholtens and Kang, 2013). This implies that high-QVD banks are mostly large-sized ones and facing stronger monitoring mechanisms employed by regulators to prevent their engagement in any potential EM-related issues (Kim et al., 2012).

\section{INSERT TABLE (VI)}

\section{Robustness test}

Our study employs several alternative analyses to examine the robustness of our main findings. Firstly, we used an alternative EM measure to determine the robustness of the primary findings to various earnings manipulation measures. Specifically, we use Jones' model, modified for banking institutions (Yasuda et al., 2004), We estimated the total accruals (TO_AC) as the variation between net income and operating cash flows.

$$
\text { TO_AC } C_{\text {it }}=\text { NE_I } I_{i t}-O C \_F_{i t}
$$

Following Abdelsalam et al. (2016) and Yasuda et al. (2004), the cross-sectional variation is utilised. We used the non-discretionary of equipment and premises expenses alongside with the changes in operating income to measure non-discretionary accruals. And therefore, the residual from equation (D) is utilised as the discretionary portion of the total accrual since it is directly related to managerial discretion. In line with Abdelsalam et al. (2016), all variables are divided by the value of lagged total assets to avoid heteroscedasticity. 


$$
\frac{T O_{-} A C}{T O_{-} A_{t-1}}=\beta_{0} \frac{1}{T O_{-} A_{t-1}}+\beta_{1} \frac{\Delta O_{-} I N_{i t}}{T O_{-} A_{t-1}}+\beta_{2} \frac{B P_{-} E_{i t}}{T O_{-} A_{t-1}}+\varepsilon_{i t}
$$

Where:

TO_AC $=$ is the total accruals estimated from the difference between net income and operation cash flows. TO_A $=$ Total assets. $\Delta \mathrm{O} \_\mathrm{IN}=$ Change in operating income. BP_E= Bank's premises and equipment. Consequently, we repeated the main empirical analyses (see Table VII) using the alternative measure as a proxy of EM.

The results are similar to the main findings in Table IV. This means that our primary results are robust to alternative EM proxies. Secondly, we tested the influence of each dimension on both measurements of earnings management separately. Table VIII reveals that the ST_RQ, which represents the quantity dimension of disclosed information, has an insignificant relationship in reducing EM in both models. On the other hand, the spread and usefulness dimensions of disclosed information have negative and significant associations in mitigating EM in both models. These results are supportive of the main outcomes and consistent with the argument that the quality of disclosed information is not directly linked with the level (quantity) (Beattie et al., 2004). However, the quality of information is more likely to be linked to both the spread and the usefulness of the disclosed information. Furthermore, we re-run the model without the additional explanatory variables, which might have influenced the main relationship between EM and QVD. The findings in Table IX support the main findings. It also confirms that the spread and usefulness dimensions are negatively and significantly attributed to EM, whereas, the quantity dimension has an insignificant association with EM. These results are corroborated with the debate that the quality of disclosed information is unlikely to be associated only with the level of disclosed information but also to the spread and the usefulness of this information (Beretta and Bozzolan, 2008; Beattie et al., 2004).

Finally, previous studies have suggested that managerial decisions affect both VD and EM, which will possibly lead to endogeneity issues (Harris et al., 2019; Rezaee and Tuo, 2019; Wang et al., 2016). Following Elnahass et al. (2018), we conducted the Durbin-WuHausman test to examine the existence of an endogeneity issue in our model. The findings of DurbinWuHausman is 0.5743. Although the endogeneity issue between the dependent and independent variable does not exist, the current study treated QVD as an endogenous variable, meaning that an endogeneity analysis will control the result. The current study used instrumental variable estimation (lagged QVD) to mitigate the endogeneity (Choi et al., 2013; Harris et al., 2019; Moumen et al., 2015). The two-stage least squares method was used to 
reassess the key findings (see Table X). The outcomes are qualitatively in line with those results reported earlier in Table IV. Overall, our test confirmed the robustness of the main results and is not affected by the potential existence of endogeneity problems.

\section{INSERT TABLE (VII)}

\section{INSERT TABLE (VIII)}

\section{INSERT TABLE (XI)}

\section{Conclusion}

This paper investigates the influence of QVD on EM among a sample of 106 commercial banks listed in 17 MENA emerging economies from 2006 to 2015. Two opposing viewpoints have been proposed by prior studies to explicate the association between QVD and EM. One view suggests that banks issue VD to reduce information asymmetry and uncertainty risk, thereby improving investment decisions in capital markets. The other view is based on the premise that the banks' managers may disguise their opportunistic (EM) behaviour by disclosing more information voluntarily. One main gap that is not addressed by previous studies relates to the methods used to evaluate VD. Our study contributes to the extant literature by distinctively developing a multidimensional proxy for QVD and examining whether QVD can constrain EM. We combined three dimensions to measure QVD: the quantity, spread and usefulness of disclosed information. Using the OLS regression model, we found that QVD has a negative impact on EM. Our study adds to the ongoing debate on the possible effects of QVD on EM by providing new empirical evidence suggest that banks with QVD are, in fact, less likely to manipulate earnings, and instead will offer more transparent and reliable information in the context of developing economies generally and the MENA setting specifically. This evidence is in line with the perspective of signalling theory. Additionally, the influence of the quantity dimension of the disclosed information has an insignificant relationship in reducing EM, whereas, the spread and usefulness dimensions of disclosed information have a negative and significant association with EM. These outcomes support the argument that the quality of the disclosed information is not directly linked with the level (quantity) of disclosure, though the quality of information is more likely to be related to the spread and the usefulness of the information.

This study offers several implications for bank managers, academics, and policy-makers. Firstly, it may help managers to appreciate the function and the importance of QVD in 
mitigating EM. Secondly, for academics, our study provides suggestive evidence on the impact of QVD on EM; however, future research may need to consider the role of morality and ethical behaviour across different environments in reducing excessive risk-taking and constraining earnings manipulation. Finally, it provides insights for policy-makers and regulators to develop a framework or guidance that can help banks in providing high-QVD in the context of developing economies.

Although our results are robust to various measurements and the possible occurrence of endogeneity problems, there are a few limitations that should be acknowledged, which provides opportunities for future research. For example, our sample size is relatively small due to data accessibility issues. Likewise, the findings of our research might not be appropriate for nonfinancial sectors. These limitations provide a good opportunity for future studies to expand on our research by covering other developing economies and, thereby, enriching the understanding offered by this study.

\section{References}

Abdelsalam, O., \& El-Komi, M. (2016). Islamic finance: Introduction and implications for future research and practice. Journal of Economic Behavior \& Organization., 132, pp. 1-3.

Abdelsalam, O., Dimitropoulos, P., Elnahass, M., \& Leventis, S. (2016). Earnings management behaviors under different monitoring mechanisms: The case of Islamic and conventional banks. Journal of Economic Behavior \& Organization, 132, 155-173.

Ahmed, A. S., Takeda, C., \& Thomas, S. (1999). Bank loan loss provisions: a reexamination of capital management, earnings management and signaling effects. Journal of accounting and economics, 28(1), 125.

Ahmed, K., \& Courtis, J. K. (1999). Associations between corporate characteristics and disclosure levels in annual reports: a meta-analysis. The British Accounting Review, 31(1), 35-61.

Ahmed, A.S., Takeda, C. and Thomas, S., (1999). Bank loan loss provisions: a reexamination of capital management, earnings management and signaling effects. Journal of accounting and economics, 28(1), pp.125 .

Akisik, O., \& Gal, G. (2011). Sustainability in businesses, corporate social responsibility, and accounting standards: An empirical study. International Journal of Accounting and Information Management, 19(3), 304-324.

Ashraf, A., Hassan, M. K., \& Putnam, K. (2014). The effects of prudential regulatory regimes and accounting standards on earnings management of loan loss provisions in the banking industry. Cell, 301, 338-0934.

Alhadab, M. and Al-Own, B. (2019), Earnings management and equity incentives: evidence from the European banking industry, International Journal of Accounting \& Information Management, Vol. 27 No. 2, pp. 244 261.

Alotaibi, K. O., \& Hussainey, K. (2016). Quantity versus quality: The value relevance of CSR disclosure of Saudi companies. Corporate Ownership and Control, 13(2).

Alturki, K. (2014). Voluntary disclosure by Saudi companies. Research Journal of Finance and Accounting, 5(20), pp.77-94. 
Alzoubi, E.S.S., (2016). Disclosure quality and earnings management: Evidence from Jordan. Accounting Research Journal, 29(4), pp.429-456.

Alzoubi, E.S. (2016), Ownership structure and earnings management: evidence from Jordan, International Journal of Accounting and Information Management, Vol. 24 No. 2, pp. 135-161.

Beattie, V., McInnes, B. and Fearnley, S. (2004) September. A methodology for analysing and evaluating narratives in annual reports: a comprehensive descriptive profile and metrics for disclosure quality attributes. In Accounting forum 28, (3), pp. 205-236.

Beaver, W. H., \& Engel, E. E. (1996). Discretionary behaviour with respect to allowances for loan losses and the behaviour of security prices. Journal of Accounting and Economics, 22(1), 177-206.

Belgacem, I., \& Omri, A. (2015). Does corporate social disclosure affect earnings quality? Empirical evidence from Tunisia. International Journal, Adv. Res, 3, pp.73-89.

Othman, H. B., \& Mersni, H. (2014). The use of discretionary loan loss provisions by Islamic banks and conventional banks in the Middle East region. Studies in Economics and Finance. 31(1), pp.106-128.

Ben Rejeb Attia, M., Lassoued, N. and Sassi, H. (2019). Financial reporting timeliness and the value relevance of earnings: Evidence from banks in the MENA countries. The International Trade Journal, 33(3), 277-301.

Beretta, S., \& Bozzolan, S. (2008). Quality versus quantity: The case of forward-looking disclosure. Journal of Accounting, Auditing \& Finance, 23 (3), pp. 333-376.

Bigus, J., and Häfele, S., (2018). Shareholder Loans and Earnings Smoothing-Empirical Findings from German Private Firms. European Accounting Review, 27(1), pp.37-74.

Bourgain, A., Pieretti, P. and Zanaj, S. (2012). Financial openness, disclosure and bank risk-taking in MENA countries. Emerging Markets Review, 13(3), pp.283-300.

Botosan, C. A. (2004). Discussion of a framework for the analysis of firm risk communication. The International Journal of Accounting, 39(3), 289-295.

Brusca, I., Rossi, F. and Aversano, N. (2016), "Online sustainability information in local governments in an austerity context: an empirical analysis in Italy and Spain”, Online Information Review, Vol. 40 No. 4, pp. 497-514

Bushman, R. M., \& Smith, A. J. (2001). Financial accounting information and corporate governance. Journal of Accounting and Economics, 32 (1), pp. 237-333.

Buallay, A., Fadel, S. M., Al-Ajmi, J. Y., \& Saudagaran, S. (2020). Sustainability reporting and performance of MENA banks: Is there a trade-off?. Measuring Business Excellence.

Cahan, S. F., De Villiers, C., Jeter, D. C., Naiker, V., \& Van Staden, C. J. (2016). Are CSR disclosures value relevant? Cross-country evidence. European Accounting Review, 25 (3), pp. 579-611.

Cai, G., Li, W., \& Tang, Z. (2020). Religion and the method of earnings management: Evidence from China. Journal of Business Ethics, 161(1), 71-90.

Chatterji, A. K., Levine, D. I., \& Toffel, M. W. (2009). How well do social ratings actually measure corporate social responsibility? Journal of Economics \& Management Strategy, 18 (1), pp. 125-169.

Choi, B. B., Lee, D., \& Park, Y. (2013). Corporate social responsibility, corporate governance and earnings quality: Evidence from Korea. Corporate Governance: An International Review, 21 (5), pp. 447-467.

Chong, G., Huang, H. and Zhang, Y. (2012), Do US commercial banks use FAS 157 to manage earnings?, International Journal of Accounting and Information Management, Vol. 20 No. 1, pp. 78-93.

Cornett, M. M., McNutt, J. J., \& Tehranian, H. (2009). Corporate governance and earnings management at large US bank holding companies. Journal of Corporate Finance, 15 (4), pp.412-430.

Darjezi, J.I. (2016), The role of accrual estimation errors to determine accrual and earnings quality, International Journal of Accounting and Information Management, Vol. 24 No. 2, pp. 98-115.

Ding, Y., Zhang, H., \& Zhang, J. (2007). Private vs state ownership and earnings management: Evidence from Chinese listed companies. Corporate Governance: An International Review, 15 (2), pp.223-238.

Elamer, A.A., Ntim, C.G. and Abdou, H.A., (2020). Islamic governance, national governance, and bank risk management and disclosure in MENA countries. Business \& Society, 59(5), pp.914-955.

Elfeituri, H. (2018). Market concentration, foreign ownership and determinants of bank financial performance: evidence from MENA countries. Corporate Ownership and Control, 15(3), 9-22.

Elnahass, M., Izzeldin, M., \& Abdelsalam, O. (2014). Loan loss provisions, bank valuations and discretion: A comparative study between conventional and Islamic banks. Journal of Economic Behavior \& Organization, 103, S160-S173.

Elnahass, M., Izzeldin, M., \& Steele, G. (2018). Capital and earnings management: evidence from alternative banking business models. The International Journal of Accounting, 53(1), 20-32.

Elleuch, S. H., \& Taktak, N. B. (2015). Earnings management and evolution of the banking regulation. Journal of Accounting in Emerging Economies. 5 (2), 150-169.

Francis, J., Nanda, D., \& Olsson, P. (2008). Voluntary disclosure, earnings quality, and cost of capital. Journal of Accounting Research, 46 (1),53-99. 
Gerged, A. M., Al-Haddad, L. M., \& Al-Hajri, M. O. (2020). Is earnings management associated with corporate environmental disclosure?: Evidence from Kuwaiti listed firms. Accounting Research Journal, 33(1), 167185.

Ghosh, S. (2018). Governance reforms and performance of MENA banks: Are disclosures effective?. Global Finance Journal, 36, 78-95.

Gray, R.P. and Clarke, F.L., (2004). A methodology for calculating the allowance for loan losses in commercial banks. Abacus, 40(3), pp.321-341.

Grougiou, V., Leventis, S., Dedoulis, E., \& Owusu-Ansah, S. (2014). Corporate social responsibility and earnings management in US banks. In Accounting Forum (Vol. 38, No. 3, pp. 155-169). Taylor \& Francis.

Gujarati, DNN and Porter, D., (2009). Basic Econometrics. Mc Graw-Hill International Edition.

Habbash, M., Hussainey, K., \& Awad, A. E. (2016). The determinants of voluntary disclosure in Saudi Arabia: An empirical study. International Journal of Accounting, Auditing and Performance Evaluation, 12(3), 213236.

Hadani, M., Goranova, M., \& Khan, R. (2011). Institutional investors, shareholder activism, and earnings management. Journal of Business Research, 64(12), 1352-1360.

Haniffa, R., \& Hudaib, M. A. (2002). A theoretical framework for the development of the Islamic perspective of accounting. Accounting, Commerce and Finance: The Islamic Perspective Journal, 6(1/2), 1-71.

Haniffa, R. M., \& Cooke, T. E. (2005). The impact of culture and governance on corporate social reporting. Journal of Accounting and Public Policy, 24(5), 391-430.

Harris, O., Karl, J.B. and Lawrence, E., (2019). CEO compensation and earnings management: Does gender really matters?. Journal of Business Research, 98, 1-14.

Harun, M.S., Hussainey, K., Kharuddin, K.A.M. and Al Farooque, O., (2020). CSR disclosure, corporate governance and firm value: a study on GCC Islamic banks. International Journal of Accounting \& Information Management.

Husted, B. W., \& De Sousa-Filho, J. M. (2018). Board structure and environmental, social, and governance disclosure in Latin America. Journal of Business Research.

Iatridis, G., \& Kadorinis, G. (2009). Earnings management and firm financial motives: A financial investigation of UK listed firms. International Review of Financial Analysis, 18 (4), 164-173.

IFRS. (2010). Practice statement, MC, A framework for presentation. International Financial Reporting Standard, London: UK.

Jackson, A.B., 2018. Discretionary Accruals: Earnings Management... or Not?. Abacus, 54(2), pp.136-153.

Jensen, M.C. and Meckling, WHH, (1976). Theory of the firm: Managerial behavior, agency costs and ownership structure. Journal of financial economics, 3(4), pp.305-360.

Jones, S., \& Finley, A. (2011). Have IFRS made a difference to intra-country financial reporting diversity? The British Accounting Review, 43(1), 22-38.

Kamla, R. (2007). Critically appreciating social accounting and reporting in the Arab MiddleEast: A postcolonial perspective. Advances in International Accounting, 20, 105-177.

Katmon, N. and Al Farooque, O., (2017). Exploring the impact of internal corporate governance on the relation between disclosure quality and earnings management in the UK listed companies. Journal of Business Ethics, 142(2), 345-367.

Kanagaretnam, K., Krishnan, G. V., \& Lobo, G. J. (2010). An empirical analysis of auditor independence in the banking industry. The Accounting Review, 85(6), 2011-2046.

Kanagaretnam, K., Lobo, G. J., \& Mathieu, R. (2004). Earnings management to reduce earnings variability: Evidence from bank loan loss provisions. Review of Accounting and Finance, 3(1), pp.128-148.

Kasznik, R. (1999). On the association between voluntary disclosure and earnings management. Journal of Accounting Research, 37(1), 57-81.

Kim, Y., Park, M. S., \& Wier, B. (2012). Is earnings quality associated with corporate social responsibility? The Accounting Review, 87(3), 761-796.

Klein, A. (2002). Audit committee, board of director characteristics, and earnings management. Journal of Accounting and Economics, 33(3), 375-400.

Kwak, W., Lee, H., \& Eldridge, S. W. (2009). Earnings management by Japanese bank managers using discretionary loan loss provisions. Review of Pacific Basin Financial Markets and Policies, 12 (1), pp.1-26.

Lassoued, N., Attia, M. B. R., \& Sassi, H. (2018). Earnings management in Islamic and conventional banks: does ownership structure matter? Evidence from the MENA region. Journal of International Accounting, Auditing and Taxation, 30, 85-105.

Leventis, S., Dimitropoulos, P. E., \& Anandarajan, A. (2012). Signalling by banks using loan loss provisions: The case of the European Union. Journal of Economic Studies, 39(5), 604-618.

Li, J., Mangena, M., \& Pike, R. (2012). The effect of audit committee characteristics on intellectual capital disclosure. The British Accounting Review, 44(2),.98-110. 
Lim, S. J., Lim, S. J., White, G., White, G., Lee, A., Lee, A. Yuningsih, Y. (2017). A longitudinal study of voluntary disclosure quality in the annual reports of innovative firms. Accounting Research Journal, 30(12), 89-106.

Lin, J. W., \& Hwang, M. I. (2010). Audit quality, corporate governance, and earnings management: A meta analysis. International Journal of Auditing, 14(1), 57-77.

Lin, Y., \& Shen, C. (2015). Family firms' credit rating, idiosyncratic risk, and earnings management. Journal of Business Research, 68(4), 872-877.

Lobo, G. J., \& Zhou, J. (2001). Disclosure quality and earnings management. Asia-Pacific Journal of Accounting \& Economics, 8 (1), 1-20.

Maali, B., Casson, P., \& Napier, C. (2006). Social reporting by Islamic banks. Abacus, 42(2), 266-289.

Martínez Ferrero, J., Garcia Sanchez, I. M., \& Cuadrado Ballesteros, B. (2015). Effect of financial reporting quality on sustainability information disclosure. Corporate Social Responsibility and Environmental Management, 22(1), 45-64.

Meek, G. K., Roberts, C. B., \& Gray, S. J. (1995). Factors influencing voluntary annual report disclosures by US, UK and continental European multinational corporations. Journal of International Business Studies, 26 (3), $555-572$.

Menicucci, E. (2013). The determinants of forward-looking information in management commentary: Evidence from Italian listed companies. International Business Research, 6 (5), 30.

Mersni, H., \& Othman, H. B. (2016). The impact of corporate governance mechanisms on earnings management in Islamic banks in the Middle East region. Journal of Islamic Accounting and Business Research. 7 (4), 318-348.

Michelon, G., Pilonato, S., \& Ricceri, F. (2015). CSR reporting practices and the quality of disclosure: An empirical analysis. Critical Perspectives on Accounting, 33 (2), 59-78.

Miller, G. S. (2002). Earnings performance and discretionary disclosure. Journal of Accounting Research, 40 (1), 173-204.

Moumen, N., Othman, H. B., \& Hussainey, K. (2015). The value relevance of risk disclosure in annual reports: Evidence from MENA emerging markets. Research in International Business and Finance, 34, 177-204.

Moumen, N., Othman, H.B. and Hussainey, K. (2016). Board structure and the informativeness of risk disclosure: Evidence from MENA emerging markets. Advances in Accounting, 35, 82-97.

Muttakin, M. B., Khan, A., \& Azim, M. I. (2015). Corporate social responsibility disclosures and earnings quality: Are they a reflection of managers' opportunistic behavior? Managerial Auditing Journal, 30(3), 277-298.

Nekhili, M., Nagati, H., Chtioui, T., \& Rebolledo, C. (2017). Corporate social responsibility disclosure and market value: Family versus nonfamily firms. Journal of Business Research, 77, 41-52.

Parvin, R., Rana, M.S. and Shams, S., (2020). Literature Review on the Association between Earnings Management and Corporate Social Responsibility. International Journal of Accounting \& Finance Review, 5(1), pp.22-31.

Patten, D. M., \& Trompeter, G. (2003). Corporate responses to political costs: An examination of the relation between environmental disclosure and earnings management. Journal of Accounting and Public Policy, 22(1), 83-94.

Platonova, E., Asutay, M., Dixon, R. and Mohammad, S., (2018). The impact of corporate social responsibility disclosure on financial performance: Evidence from the GCC Islamic banking sector. Journal of Business Ethics, 151(2), 451-471.

Prado-Lorenzo, J. M., Gallego-Álvarez, I., García-Sánchez, I. M., \& Rodríguez-Domínguez, L. (2008). Social responsibility in Spain: Practices and motivations in firms. Management Decision, 46(8), 1247-1271.

Prior, D., Surroca, J., \& Tribó, J. A. (2008). Are socially responsible managers really ethical? Exploring the relationship between earnings management and corporate social responsibility. Corporate Governance: An International Review, 16(3), 160-177.

Rezaee, Z. and Tuo, L., (2019). Are the quantity and quality of sustainability disclosures associated with the innate and discretionary earnings quality?. Journal of Business Ethics, 155(3), 763-786.

Rodríguez-Ariza, L., Cuadrado-Ballesteros, B., Martínez-Ferrero, J., \& García-Sánchez, I. M. (2017). The role of female directors in promoting CSR practices: An international comparison between family and non-family businesses. Journal of Business Ethics: A European Review, 26(2), 162-174.

Sanjaya, I. P. S., \& Young, L. (2012). Voluntary disclosure and earnings management at bank companies listed in Indonesia Stock Exchange. China-USA Business Review, 11(3).

Scholtens, B., \& Kang, F. (2013). Corporate social responsibility and earnings management: Evidence from Asian economies. Corporate Social Responsibility and Environmental Management, 20(2), 95-112.

Shleifer, A., \& Vishny, R. W. (1997). A survey of corporate governance. The Journal of Finance, 52(2), 737-783.

Spence, Michael, 1973, Job Market Signaling, Quarterly Journal of Economics 87(3), 355-374.

Sun, L., \& Rath, S. (2010). Earnings management research: A review of contemporary research methods. Global Review of Accounting and Finance, 1(1), 121-135. 
Suteja, J., Gunardi, A. and Mirawati, A., (2016). Moderating effect of earnings management on the relationship between corporate social responsibility disclosure and profitability of banks in Indonesia. International Journal of Economics and Financial Issues, 6(4), 1360-1365.

Tariverdi, Y., Moradzadehfard, M., \& Rostami, M. (2012). The effect of earnings management on the quality of financial reporting. African Journal of Business Management, 6(12), 4603-4611.

Turk-Ariss, R. (2009). Competitive behavior in Middle East and North Africa banking systems. The Quarterly Review of Economics and Finance, 49(2), 693-710.

Ullah, M.S., Muttakin, M.B. and Khan, A., (2019). Corporate governance and corporate social responsibility disclosures in insurance companies. International Journal of Accounting \& Information Management.

Uyar, A., Kilic, M., \& Bayyurt, N. (2013). Association between firm characteristics and corporate voluntary disclosure: Evidence from Turkish listed companies. Intangible Capital, 9(4),.1080-1112.

Wang, H., Tong, L., Takeuchi, R., \& George, G. (2016). Corporate social responsibility: An overview and new research directions thematic issue on corporate social responsibility. Academy of Management Journal, 59(2), 534-544.

Watts, R. L., \& Zimmerman, J. L. (1990). Positive accounting theory: A ten-year perspective. Accounting Review, 33 (2), 131-156.

Watts, R.L. and Zimmerman, J.L., (1978). Towards a positive theory of the determination of accounting standards. Accounting review, pp.112-134.

Yasuda, Y., Okuda, S., \& Konishi, M. (2004). The relationship between bank risk and earnings management: Evidence from Japan. Review of Quantitative Finance and Accounting, 22(3), 233-248. 


\section{Table I Banks' Specialisation by Countries}

\begin{tabular}{llcc} 
No & Country & $\begin{array}{c}\text { Number of } \\
\text { banks }\end{array}$ & \% \\
\hline 1 & Algeria & 0 & $0.00 \%$ \\
2 & Bahrain & 13 & $12.3 \%$ \\
3 & Djibouti & 0 & $0.00 \%$ \\
4 & Egypt & 5 & $4.7 \%$ \\
5 & Iraq & 2 & $1.9 \%$ \\
6 & Iran & 2 & $1.9 \%$ \\
7 & Israel & 3 & $2.8 \%$ \\
8 & Jordan & 12 & $11.3 \%$ \\
9 & Kuwait & 8 & $7.6 \%$ \\
10 & Lebanon & 2 & $1.9 \%$ \\
11 & Libya & 0 & $0.00 \%$ \\
12 & Morocco & 4 & $3.7 \%$ \\
13 & Oman & 4 & $3.7 \%$ \\
14 & Qatar & 6 & $5.7 \%$ \\
15 & Saudi Arabia & 9 & $8.5 \%$ \\
16 & Syria & 6 & $5.7 \%$ \\
17 & Tunisia & 7 & $6.6 \%$ \\
18 & UEA & 18 & $17 \%$ \\
19 & West Bank and & 4 & $3.7 \%$ \\
& Gaza & & \\
20 & Yemen & 1 & $1 \%$ \\
& Total & $\mathbf{1 0 6 *}$ & $\mathbf{1 0 0 \%}$ \\
& Toral & & \\
\hline & & & \\
& & &
\end{tabular}

*Number of banks in the study sample which are listed in MENA countries and have complete data across a ten-year period (2006-2015). 
Table II Descriptive statistics

\begin{tabular}{|c|c|c|c|c|c|}
\hline $\begin{array}{l}\text { Variables } \\
\text { Dependent Variable }\end{array}$ & Mean & Median & S. D & Min & Max \\
\hline EM_LLP & 0.1115 & 0.1025 & 0.1299 & 0.0004 & 0.9970 \\
\hline \multicolumn{6}{|c|}{ Explanatory variables } \\
\hline QVD & 0.5774 & 0.5750 & 0.0530 & 0.2380 & 0.7679 \\
\hline I_BD & 0.2899 & 0.3000 & 0.2672 & 0 & 0.9090 \\
\hline B_Z & 9.0150 & 9 & 2.9361 & 3 & 16 \\
\hline BD_EX & 0.7867 & 0.4530 & 0.4097 & 0.2857 & 1.00 \\
\hline D_U & 0.2476 & 0 & 0.4104 & 0 & 1.00 \\
\hline B GD & 0.0143 & 0 & 0.0350 & 0 & 0.3333 \\
\hline B_M & 4.7216 & 5 & 2.3513 & 1 & 11 \\
\hline I_AC & 0.4869 & 5 & 0.4279 & 0 & 1.00 \\
\hline A_CZ & 3.0575 & 3 & 0.9478 & 2 & 6 \\
\hline A_CM & 4.5603 & 4 & 1.0252 & 4 & 11 \\
\hline A_CEX & 0.5462 & 0.5012 & 0.4980 & 0.3333 & 1.00 \\
\hline $\mathrm{BIG}_{-} 4$ & 0.5773 & 1 & 0.4942 & 0 & 1.00 \\
\hline A_CG & 0.0339 & 0 & 0.1812 & 0 & 0.3333 \\
\hline M_OS & 0.0441 & 0 & 0.1255 & 0 & 0.8590 \\
\hline B_H & 0.2976 & 0.2157 & 0.3151 & $6.68 \mathrm{e}-07$ & 0.9838 \\
\hline BSIZE & 7.6594 & 3.2900 & 8.0071 & 0.0003 & 32.8636 \\
\hline GWTH & 0.1471 & 0.1247 & 0.1103 & 0.0001 & 0.9275 \\
\hline L_EV & 0.8522 & 0.8784 & 0.1291 & -0.4179 & 0.9676 \\
\hline P_ROF & 0.4427 & 0.1726 & 0.4701 & -0.4435 & 2.1250 \\
\hline L_IQ & 1.4554 & 1.1381 & 4.0767 & -2.3924 & 87.5589 \\
\hline $\mathrm{CR}$ & 0.0308 & 0.0075 & 0.1591 & -0.0915 & 4.1011 \\
\hline CAP & 0.1548 & 0.1218 & 0.1692 & 0.0071 & 2.3688 \\
\hline LD & 0.8324 & 0.8623 & 0.3889 & 0 & 4.8292 \\
\hline GCC & 0.5471 & 1 & 0.4980 & 0 & 1 \\
\hline PT & 0.1990 & 0 & 0.3994 & 0 & 1 \\
\hline
\end{tabular}


Table III Correlation matrices analysis

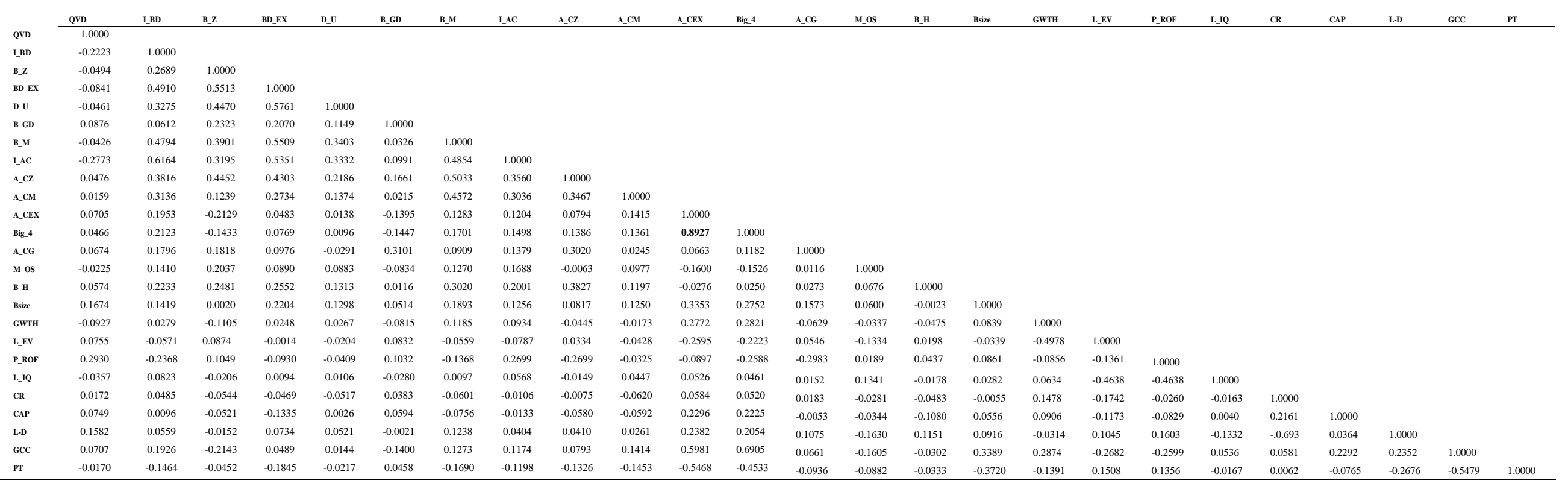


Table IV Regression result for the relationship between EM and QVD.

\begin{tabular}{lccc} 
EM_LLP & & & \\
\hline Variables & Coef. & $\mathbf{Z}$ & $\mathbf{P}>|\mathbf{z}|$ \\
QVD & -0.1042 & -3.38 & $0.001 * * *$ \\
I_BD & 0.0168 & 1.04 & 0.298 \\
B_Z & 0.0014 & 0.94 & 0.346 \\
BD_EX & -0.0113 & -1.14 & 0.252 \\
D_U & -0.0022 & -0.20 & 0.840 \\
B_GD & -0.0483 & -0.48 & 0.630 \\
B_M & 0.0004 & 0.29 & 0.771 \\
I_AC & -0.0153 & -1.57 & 0.117 \\
A_CZ & 0.0053 & 1.33 & 0.183 \\
A_CM & -0.0011 & -0.33 & 0.739 \\
Big_4 & -0.0313 & -2.69 & $0.007 * * *$ \\
A_CG & 0.0233 & 0.88 & 0.380 \\
M_OS & -0.0116 & -0.29 & 0.770 \\
B_H & -0.0407 & -2.68 & $0.007 * * *$ \\
Bsize & -0.0026 & -1.98 & $0.048 * *$ \\
GWTH & -0.1123 & -4.08 & $0.001 * * *$ \\
P_ROF & -0.0101 & -1.15 & 0.251 \\
L_EV & -0.0331 & -0.98 & 0.326 \\
L_IQ & -0.0013 & -2.45 & $0.014 * *$ \\
CR & 0.0176 & 1.17 & 0.241 \\
CAP & -0.0079 & -0.44 & 0.661 \\
L-D & -0.0258 & -3.12 & $0.002^{* * *}$ \\
GCC & 0.0147 & 0.54 & 0.590 \\
PT & 0.0324 & 1.13 & 0.259 \\
_Cons & 0.2695 & 6.08 & 0.001 \\
\hline R-sq: 0.1554, Prob $>$ Chi2: 0.001 & & \\
*****and * indicate & the significance of coefficient at 0.01, o.05, and 0.10 levels \\
respectively. & & &
\end{tabular}


Table V Results of the relationship between EM and both QD and QVD

\begin{tabular}{|c|c|c|c|c|}
\hline \multicolumn{3}{|c|}{ Model 2} & \multicolumn{2}{|c|}{ Model 1} \\
\hline \multicolumn{3}{|c|}{ QD } & \multicolumn{2}{|c|}{ QQVD } \\
\hline Variables & Coef. & $\mathbf{Z}$ & Coef. & $\mathbf{Z}$ \\
\hline QD/QVD & -0.0004 & -1.50 & $-0.1042 * * *$ & -3.38 \\
\hline I_BD & 0.0168 & 1.04 & 0.0168 & 1.04 \\
\hline $\bar{B} \_\mathrm{Z}$ & 0.0015 & 0.97 & 0.0014 & 0.94 \\
\hline BD_EX & -0.0106 & -1.07 & -0.0113 & -1.14 \\
\hline D_Ē & -0.0037 & -0.34 & -0.0022 & -0.20 \\
\hline B_GD & -0.0350 & -0.35 & -0.0483 & -0.48 \\
\hline B_M & 0.0007 & 0.47 & 0.0004 & 0.29 \\
\hline I_AC & -0.0160 & -1.64 & -0.0153 & -1.57 \\
\hline A_CZ & 0.0049 & 1.23 & 0.0053 & 1.33 \\
\hline A_CM & -0.0011 & -0.34 & -0.0011 & -0.33 \\
\hline Big_4 & $-0.0308 * * *$ & -2.65 & $-0.0313 * * *$ & -2.69 \\
\hline A_CG & 0.0180 & 0.67 & 0.0233 & 0.88 \\
\hline M_OS & -0.0121 & -0.30 & -0.0116 & -0.29 \\
\hline B_H & $-0.0382 * * *$ & -2.49 & $-0.0407 * * *$ & -2.68 \\
\hline Bsize & $-0.0025^{*}$ & -1.86 & $-0.0026 * *$ & -1.98 \\
\hline GWTH & $-0.1101 * * *$ & -4.00 & $-0.1123 * * *$ & -4.08 \\
\hline P_ROF & -0.0116 & -1.11 & -0.0101 & -1.15 \\
\hline L_EV & -0.0301 & -1.04 & -0.0331 & -0.98 \\
\hline L_IQ & $-0.0013^{* *}$ & -2.44 & $-0.0013 * *$ & -2.45 \\
\hline$\overline{C R}$ & 0.0180 & 1.20 & 0.0176 & 1.17 \\
\hline CAP & -0.0097 & -0.53 & -0.0079 & -0.44 \\
\hline L-D & $-0.0268 * * *$ & -3.23 & $-0.0258 * * *$ & -3.12 \\
\hline GCC & 0.0162 & 0.57 & 0.0147 & 0.54 \\
\hline PT & 0.0353 & 1.19 & 0.0324 & 1.13 \\
\hline _Cons & 0.2070 & 5.07 & 0.2695 & 6.08 \\
\hline Model 2, R-sq: & Prob > Chi2: 0.00 & & del 1, R-sq: 0.1554 & Chi2: 0.001 \\
\hline
\end{tabular}


Table VI Results of the relationship between EM and high/ low QVD

EM LLP

\begin{tabular}{|c|c|c|c|c|}
\hline \multicolumn{3}{|c|}{ High QVD } & \multicolumn{2}{|c|}{ Low QVD } \\
\hline Variables & Coef. & $\mathbf{Z}$ & Coef. & $\mathbf{Z}$ \\
\hline High QVD/Low & $-0.2045^{* * *}$ & -3.90 & -0.0248 & -0.40 \\
\hline QVD & & & & \\
\hline I_BD & 0.0242 & 0.80 & 0.0025 & 0.16 \\
\hline B_Z & 0.0026 & 0.89 & -0.0002 & -0.15 \\
\hline BD̄EEX & $-0.0412 * *$ & -2.09 & -0.0013 & -0.15 \\
\hline D_U & 0.0104 & 0.47 & -0.0092 & -0.92 \\
\hline B_GD & -0.1048 & -0.54 & -0.0349 & -0.39 \\
\hline B_M & 0.0018 & 0.50 & 0.0003 & 0.28 \\
\hline I_AC & $-0.0477 * * *$ & -2.66 & 0.0056 & 0.58 \\
\hline A_CZ & 0.0107 & 1.46 & 0.0021 & 0.52 \\
\hline A_CM & -0.0059 & -0.84 & 0.0003 & 0.13 \\
\hline Big_4 & $-0.0351 * *$ & -1.99 & $-0.0268 * *$ & -2.21 \\
\hline A_CG & -0.0064 & -0.07 & 0.0180 & 0.93 \\
\hline M_OS & -0.0011 & -0.02 & -0.0270 & -0.68 \\
\hline B_H & $-0.0352 * * *$ & -2.29 & $-0.0371 * * *$ & -2.76 \\
\hline Bsize & $-0.0024 * *$ & -2.11 & $-0.0027 * * *$ & -2.48 \\
\hline GWTH & $-0.1644 * * *$ & -3.27 & -0.0306 & -1.08 \\
\hline P_ROF & -0.0037 & -0.23 & -0.0087 & -0.82 \\
\hline L_EV & -0.0507 & -0.98 & -0.0053 & -0.11 \\
\hline L_IQ & $-0.0017 * *$ & -2.14 & -0.0006 & -0.48 \\
\hline $\mathrm{CR}$ & 0.0167 & 0.49 & 0.0072 & -0.18 \\
\hline CAP & -0.0297 & -0.49 & 0.0155 & -1.14 \\
\hline L-D & $-0.0159 * *$ & -2.09 & $0.0885 * * *$ & -5.67 \\
\hline GCC & 0.0181 & 0.52 & 0.0304 & 1.13 \\
\hline PT & 0.0292 & 0.89 & 0.0098 & 0.34 \\
\hline Cons & 0.3513 & 4.51 & 0.2296 & 3.24 \\
\hline
\end{tabular}


Table VII Results of panel data regression for the relationship between EM and VDQ based on modified Jones model

\begin{tabular}{lccc} 
EM_DA & \multicolumn{3}{l}{} \\
\hline Variables & Coef. & $\mathbf{Z}$ & $\mathbf{P}>|\mathbf{z}|$ \\
QVD & -0.0690 & -3.54 & $0.001^{* * *}$ \\
I_BD & -0.0209 & -2.11 & $0.035^{* *}$ \\
B_Z & -0.0023 & -2.55 & $0.011^{* * *}$ \\
BD_EX & -0.0027 & -0.43 & 0.664 \\
D_U & -0.0074 & -1.19 & 0.235 \\
B_GD & -0.0343 & -0.57 & 0.568 \\
B_M & 0.0002 & 0.22 & 0.828 \\
I_AC & 0.0079 & 1.31 & 0.189 \\
A_CZ & -0.0052 & -2.11 & $0.035^{* *}$ \\
A_CM & 0.0001 & 0.05 & 0.956 \\
Big_4 & -0.0194 & -2.62 & $0.009 * * *$ \\
A_CG & 0.0805 & 1.33 & 0.182 \\
M_OS & -0.0095 & -0.47 & 0.639 \\
B_H & 0.0139 & 1.26 & 0.119 \\
Bsize & 0.0003 & 0.20 & 0.841 \\
GWTH & 0.0043 & -0.25 & 0.805 \\
P_ROF & 0.0084 & 1.56 & 0.120 \\
L_EV & -0.0242 & -1.36 & 0.175 \\
L_IQ & 0.0003 & 1.00 & 0.361 \\
CR & -0.0054 & -0.56 & 0.576 \\
CAP & -0.0020 & -0.18 & 0.857 \\
L-D & -0.0047 & -0.93 & 0.354 \\
GCC & 0.0103 & 0.98 & 0.325 \\
PT & 0.0056 & 0.60 & 0.547 \\
-Cons & 0.1241 & 5.13 & 0.001 \\
\hline Random-effect method GLS regression, & & \\
R-sq: 0.1181, Prob $>$ Chi2: 0.001 & \\
******and*indicate the significance of coefficient at 0.01, o.05, and 0.10 levels \\
respectively. & & & \\
\hline & & &
\end{tabular}


Table VIII Results of panel data regression for the relationship between EM and three dimensions of QVD

\begin{tabular}{|c|c|c|c|c|c|c|}
\hline \multirow[b]{2}{*}{ Variables } & \multicolumn{3}{|c|}{$\begin{array}{c}\text { Model 1 } \\
\text { EM_LLP }\end{array}$} & \multicolumn{3}{|c|}{$\begin{array}{l}\text { Model } 2 \\
\text { EM_DA }\end{array}$} \\
\hline & Coef. & $\mathbf{Z}$ & $\mathbf{P}>|\mathbf{z}|$ & Coef. & $\mathbf{Z}$ & $\mathbf{P}>|\mathbf{z}|$ \\
\hline ST_RQ & -0.016 & -1.160 & 0.188 & -0.0173 & -1.70 & 0.101 \\
\hline Spread & -0.812 & -9.780 & $0.001 * * *$ & -0.4438 & -8.830 & $0.001 * * *$ \\
\hline USEFUL & -0.033 & -3.140 & $0.002 * * *$ & -0.0392 & -6.050 & $0.001 * * *$ \\
\hline I_BD & -0.039 & -2.560 & $0.011 * * *$ & -0.0209 & -2.220 & $0.026 * *$ \\
\hline B_Z & -0.002 & -1.040 & 0.299 & -0.0019 & -2.340 & $0.019 * *$ \\
\hline BD_EX & 0.001 & 0.100 & 0.922 & -0.0003 & -0.050 & 0.957 \\
\hline D_U & 0.002 & 0.220 & 0.829 & -0.0051 & -0.900 & 0.368 \\
\hline B_GD & -0.020 & -0.220 & 0.826 & -0.0254 & -0.460 & 0.648 \\
\hline B_M & 0.002 & 1.340 & 0.179 & 0.0005 & 0.540 & 0.586 \\
\hline I_AC & -0.005 & -0.510 & 0.607 & -0.0112 & -1.940 & $0.052^{*}$ \\
\hline A_CZ & -0.006 & -1.690 & 0.092 & -0.0041 & -1.870 & $0.074^{*}$ \\
\hline A_CM & 0.001 & 0.230 & 0.819 & 0.0002 & 0.110 & 0.911 \\
\hline Big_4 & -0.029 & -2.680 & $0.007 * * *$ & -0.0165 & -2.320 & $0.02 * *$ \\
\hline A_CG & -0.012 & -0.520 & 0.603 & 0.0049 & 0.400 & 0.689 \\
\hline M_OS & -0.028 & -0.780 & 0.433 & -0.0135 & -0.760 & 0.447 \\
\hline B_H & -0.016 & -1.170 & 0.240 & -0.0144 & -2.060 & $0.039 * *$ \\
\hline Bsize & -0.001 & -1.140 & 0.256 & 0.0002 & 0.610 & 0.543 \\
\hline GWTH & -0.065 & -2.530 & $0.011 * * *$ & 0.017 & 1.000 & 0.317 \\
\hline P_ROF & -0.012 & -0.440 & 0.661 & 0.0033 & 0.690 & 0.490 \\
\hline L_EV & -0.014 & -1.540 & 0.124 & -0.0157 & -0.930 & 0.352 \\
\hline L_IQ & -0.001 & -2.400 & $0.016 * * *$ & 0.0003 & 1.010 & 0.314 \\
\hline $\mathrm{CR}$ & 0.011 & 0.800 & 0.421 & -0.0036 & -0.390 & 0.697 \\
\hline CAP & 0.006 & 0.380 & 0.705 & 0.0034 & 0.330 & 0.742 \\
\hline L-D & -0.029 & -3.820 & $0.001 * * *$ & -0.0065 & -1.370 & 0.171 \\
\hline GCC & 0.037 & 1.690 & $0.09 *$ & 0.0186 & 2.030 & $0.043 * *$ \\
\hline PT & 0.024 & 1.050 & 0.294 & 0.0053 & 0.700 & 0.482 \\
\hline -Cons & 0.483 & 11.960 & $0.001 * * *$ & 0.1915 & 8.070 & $0.001 * * *$ \\
\hline \multicolumn{7}{|c|}{ Random-effect method GLS regression, } \\
\hline R-sq: 0.3824 , & o > Chi2 & & & R-sq & 237, Pro & Chi2: 0.001 \\
\hline
\end{tabular}


Table IX Results of panel data regression without control variables

\begin{tabular}{|c|c|c|c|c|c|c|}
\hline & \multicolumn{3}{|c|}{ EM_LLP } & \multicolumn{3}{|c|}{ EM_DA } \\
\hline Variables & Coef. & $\mathbf{Z}$ & $\mathbf{P}>|\mathbf{z}|$ & Coef. & $\mathbf{Z}$ & $\mathbf{P}>|\mathbf{z}|$ \\
\hline QVD & -0.10672 & -3.43 & $0.001 * * *$ & -0.0618 & -3.18 & $0.001 * * *$ \\
\hline ST_RQ & -0.0083 & -0.56 & 0.577 & -0.0201 & -1.85 & 0.121 \\
\hline Spread & -0.7837 & -9.41 & $0.001 * * *$ & -0.4289 & -8.85 & $0.001 * * *$ \\
\hline USEFUL & -0.0386 & -3.66 & $0.001 * * *$ & -0.0341 & -5.46 & $0.001 * * *$ \\
\hline
\end{tabular}


Table X Instrumental variables (2SLS regression)

EM_LLPs

\begin{tabular}{lccc}
\hline Variables & Coef. & $\mathbf{z}$ & $\mathbf{P}>|\mathbf{z}|$ \\
Lag-VDQ & -0.1048 & -6.24 & $0.001 * * *$ \\
I_BD & 0.0176 & -0.58 & 0.558 \\
B-Z & 0.0015 & -1.51 & 0.130 \\
BD_EX & -0.0114 & -2.83 & $0.005 * * *$ \\
D_U & -0.0025 & 0.24 & 0.813 \\
B_GD & -0.0491 & -1.28 & 0.200 \\
B_M & 0.0004 & -0.51 & 0.608 \\
I_AC & -0.0156 & -0.61 & 0.543 \\
A_CZ & 0.0054 & 1.63 & 0.103 \\
A_CM & -0.0010 & -1.34 & 0.180 \\
Big_4 & -0.0316 & -2.36 & $0.174 * * *$ \\
A_CG & 0.1263 & 1.21 & 0.227 \\
M_OS & -0.0117 & -0.47 & 0.636 \\
B_H & -0.0409 & -3.05 & $0.002 * * *$ \\
Bsize & -0.0026 & 0.54 & 0.592 \\
GWTH & -0.1120 & -3.57 & $0.001 * * *$ \\
P_ROF & -0.0101 & 1.96 & $0.050^{* *}$ \\
L_EV & -0.0333 & -1.40 & 0.161 \\
L_IQ & -0.0013 & -0.85 & 0.398 \\
CR & 0.0175 & -4.25 & $0.001 * * *$ \\
CAP & -0.0078 & 7.20 & 0.001 \\
L-D & -0.0258 & -3.12 & $0.002 * * *$ \\
GCC & 0.0145 & 0.53 & 0.594 \\
PT & 0.0322 & 1.12 & 0.262 \\
-Cons & 0.2704 & 6.10 & $0.001 * * *$ \\
\hline$* * * * * a n d *$ indicate the significance of coefficient at $0.01,0.05$, and 0.10 \\
levels respectively. \\
Independent variables: Lag-VDQ= is the lagged variable of VDQ.
\end{tabular}




\section{Appendix A}

\section{Checklist of Voluntary disclosure (VD) categories and items:}

\section{Background about the bank / general corporate information (7):}

Brief narrative history of the Bank

Basic organization structure / chart / description of corporate structure

General description of business activities

Date of establishment

Official address / registered address / address for correspondence.

The web address of the bank/email address

Other background information

\section{Corporate Strategy (4):}

Management's objectives and strategies / corporate vision

Future strategy- general development of business.

Impact of strategy on future results

Other corporate strategy information

\section{Corporate Governance (18)}

Details about the chairman (other than name/title).

Details about directors (other than name/title).

Duties of board members.

Number of shares held by directors.

List of top five shareholders of the bank.

Number of shares held by managers.

Details of CEO's contact address.

Definition of independent directors.

Nature of chairman of the board of directors.

Directors' engagement/directorship of other companies.

Picture of all directors/board of directors.

Picture of chairperson only.

Information about changes in board members.

The number of the board of members meetings held and date.

List of the audit committee.

Chairman's statement.

CEO's statement.

Classification of managers as executive or outsider.

4. Accounting Policies (8)

Accounting valuation of fixed assets (e.g., fair value or historical cost).

The depreciation methods used.

Foreign currency transactions.

Events after the balance sheet date

Disclosure of accounting standards uses for its accounts

Statements of compliance with approved IFRS/IASs

Treatment of contingent liabilities

Other accounting policies

5. Financial Performance (ratios) and other statistics information (16):

A brief discussion of the bank's financial position

Disclosure on non-performing loans (NPLs) / Impaired loans

Analysis of bank's liquidity position

Return on assets (ROA)

Return on equity (ROE)

Liquidity ratios. 
Earnings per share (EPS)

Capital adequacy ratios.

Total dividends.

Dividends per share for the period

Number of branches extension during the current fiscal year.

Financial statistics / financial highlights for more than one year

Comparative Income statement for 2 years.

Comparative balance sheet for 2 years.

Cash flow statement

A key achievement during the current year

6. General Risk Management (7):

Discussion of overall risk management policy

Narrative discussions on risk assets, risk measurement.

Discussion on how risk are managed and controlled.

Information on the risk management committee.

Information on assets-liability management committee.

Information on the risk management structure.

Other information on risk management

7. Credit Risk Exposure (7):

Disclosure on credit exposure

Information on credit risk management structure

Disclosures about the current loan.

Details of a problem on loans and other assets.

Disclosure of credit rating system.

Disclosure about risk management process (use of risk-mitigating tools such as collaterals, guarantees, netting agreement, managing concentrations).

Other information on risk exposure.

8. Currency and market Risk (4):

They are broken down by assets and liabilities.

Maturity of foreign currency assets and liabilities.

General descriptions of market risk segments.

Other information on market risk

9. Liquidity Risk Exposure (3):

Information about the bank's available liquid assets as well as sources and uses of funds.

Maturity information about deposits and other liabilities.

Other information on liquidity risk

10. Key Non-financial Statistics (7):

Details of branch location.

Number of branches.

Number of branch expansion during the year -2007.

Information on branch computerizations.

Information on ATM.

Location of ATM and their address.

Other non-financial information statistics

11. Corporate Social Disclosure (5):

Sponsoring public health, sporting of recreational and social projects and education.

Information on donations to charitable.

Supporting national pride / government sponsored campaigns.

Information on social banking activities / banking for the society.

Other corporate social disclosure.

12. Employee information (6):

Total number of employees.

Number of employees trained.

Policy on employees training.

Average compensation per employee. 
Information on welfare of employees.

Other employee information

13. Others:

General voluntary disclosure information (e.g. On-line banking, international banking facilities, Information on credit card) 


\section{Appendix B: The Usefulness Dimension index}

\begin{tabular}{|c|c|c|}
\hline & Depth of information disclosed & Operationalization \\
\hline \multirow{10}{*}{ Relevance } & $\begin{array}{l}\text { To what extent does the company } \\
\text { use fair value instead of historical } \\
\text { cost? }\end{array}$ & $\begin{array}{l}1=\text { Only historical cost } \\
2=\text { Mostly historical cost } \\
3=\text { Balance fair value } / \text { historical cost } \\
4=\text { Most fair value } \\
5=\text { Only fair value }\end{array}$ \\
\hline & $\begin{array}{l}\text { To what extent does the presence } \\
\text { of non-financial information in } \\
\text { terms of business opportunities } \\
\text { and risks complement the financial } \\
\text { information? }\end{array}$ & $\begin{array}{l}1=\text { No non-financial information } \\
2=\text { Limited non-financial information, not very useful } \\
\text { for forming expectations } \\
3=\text { Sufficient useful non-financial information } \\
4=\text { Relatively much useful non-financial information, } \\
\text { helpful for developing expectations } \\
5=\text { Very extensive non-financial information presents } \\
\text { additional information which helps developing } \\
\text { expectations }\end{array}$ \\
\hline & $\begin{array}{l}\text { To what extent does the risk } \\
\text { section provide good insights into } \\
\text { the risk profile of the company? }\end{array}$ & $\begin{array}{l}1=\text { No insights into risk profile } \\
2=\text { Limited insights into risk profile } \\
3=\text { Sufficient insights into risk profile } \\
4=\text { Relatively much insights into risk profile } \\
5=\text { Very extensive insights into risk profile }\end{array}$ \\
\hline & $\begin{array}{l}\text { To what extent does the annual } \\
\text { report contain forward- looking } \\
\text { information? }\end{array}$ & $\begin{array}{l}1=\text { No forward-looking information } \\
2=\text { Limited forward-looking information } \\
3=\text { Sufficient forward-looking information } \\
4=\text { Relatively much forward-looking information. } \\
5=\text { Very extensive forward-looking information }\end{array}$ \\
\hline & $\begin{array}{l}\text { To what extent does the annual } \\
\text { report contain information on } \\
\text { CSR? }\end{array}$ & $\begin{array}{l}1=\text { No information on CSR } \\
2=\text { Limited information on CSR } \\
3=\text { Sufficient information on CSR } \\
4=\text { Very much information on CSR } \\
5=\text { Very extensive information on CSR }\end{array}$ \\
\hline & $\begin{array}{l}\text { To what extent does the annual } \\
\text { report contain disclosure of the } \\
\text { extraordinary gains and losses? }\end{array}$ & $\begin{array}{l}1=\text { No proper disclosure } \\
2=\text { Limited proper disclosure } \\
3=\text { Sufficient proper disclosure } \\
4=\text { Very much proper disclosure } \\
5=\text { Very extensive proper disclosure }\end{array}$ \\
\hline & $\begin{array}{l}\text { To what extent does the annual } \\
\text { report contain information } \\
\text { regarding employee policies? }\end{array}$ & $\begin{array}{l}1=\text { No information regarding personnel policies } \\
2=\text { Limited information regarding personnel policies } \\
3=\text { Sufficient information regarding personnel policies } \\
4=\text { Very much information regarding personnel policies } \\
5=\text { Very extensive information regarding personnel } \\
\text { policies }\end{array}$ \\
\hline & $\begin{array}{l}\text { To what extent does the annual } \\
\text { report contain an analysis } \\
\text { concerning cash flows? }\end{array}$ & $\begin{array}{l}1=\text { No analysis } \\
2=\text { Limited analysis } \\
3=\text { Sufficient analysis } \\
4=\text { Very much analysis } \\
5=\text { Very extensive analysis }\end{array}$ \\
\hline & $\begin{array}{l}\text { To what extent are the intangible } \\
\text { assets disclosed? }\end{array}$ & $\begin{array}{l}1=\text { No disclosure } \\
2=\text { Limited disclosure } \\
3=\text { Sufficient disclosure } \\
4=\text { Very much disclosure } \\
5=\text { Very extensive disclosure }\end{array}$ \\
\hline & $\begin{array}{l}\text { To what extent are the "off- } \\
\text { balance" activities disclosed? }\end{array}$ & $\begin{array}{l}1=\text { No disclosure } \\
2=\text { Limited disclosure } \\
3=\text { Sufficient disclosure } \\
4=\text { Very much disclosure } \\
5=\text { Very extensive disclosure }\end{array}$ \\
\hline
\end{tabular}




\begin{tabular}{|c|c|c|}
\hline & $\begin{array}{l}\text { To what extent is the financial } \\
\text { structure disclosed? }\end{array}$ & $\begin{array}{l}1=\text { No disclosure } \\
2=\text { Limited disclosure } \\
3=\text { Sufficient disclosure } \\
4=\text { Very much disclosure } \\
5=\text { Very extensive disclosure }\end{array}$ \\
\hline & $\begin{array}{l}\text { To what extent does the annual } \\
\text { report contain information } \\
\text { concerning the bank's going } \\
\text { concern? }\end{array}$ & $\begin{array}{l}1=\text { No information concerning going concern } \\
2=\text { Limited information concerning going concern } \\
3 \text { = Sufficient information concerning going concern } \\
4 \text { = Very much information concerning going concern } \\
5=\text { Very extensive information concerning going } \\
\text { concern }\end{array}$ \\
\hline & $\begin{array}{l}\text { To what extent do the reported } \\
\text { results provide feedback to users } \\
\text { of the annual report as to how } \\
\text { various market events and } \\
\text { significant transactions affected } \\
\text { the company? }\end{array}$ & $\begin{array}{l}1=\text { No feedback } \\
2=\text { Little feedback on the past } \\
3=\text { Feedback is present } \\
4=\text { Feedback helps understanding how events and } \\
\text { transactions influenced the company } \\
5=\text { Comprehensive feedback }\end{array}$ \\
\hline \multirow{6}{*}{$\begin{array}{l}\text { Faithful } \\
\text { representati } \\
\text { on }\end{array}$} & $\begin{array}{l}\text { To what extent are valid } \\
\text { arguments provided to support the } \\
\text { decision for certain assumptions } \\
\text { and estimates in annual report? }\end{array}$ & $\begin{array}{l}1=\text { No valid arguments } \\
2=\text { Limited valid arguments } \\
3=\text { Sufficient valid arguments } \\
4=\text { Very much valid arguments } \\
5=\text { Very extensive valid arguments }\end{array}$ \\
\hline & $\begin{array}{l}\text { To what extent does the company } \\
\text { base its choice for certain } \\
\text { accounting principles on valid } \\
\text { arguments? }\end{array}$ & $\begin{array}{l}1=\text { No valid arguments } \\
2=\text { Limited valid arguments. } \\
3=\text { Sufficient valid arguments } \\
4=\text { Very much valid arguments } \\
5=\text { Very extensive valid arguments }\end{array}$ \\
\hline & $\begin{array}{l}\text { Which type of auditor's report is } \\
\text { included in the annual report? }\end{array}$ & $\begin{array}{l}1=\text { Adverse opinion } \\
2=\text { Disclaimer of opinion } \\
3 \text { = Qualified opinion } \\
4 \text { = Unqualified opinion: financial figures } \\
5=\text { Unqualified opinion: financial figures }+ \text { internal } \\
\text { control }\end{array}$ \\
\hline & $\begin{array}{l}\text { To what extent does the company } \\
\text { provide information on corporate } \\
\text { governance? }\end{array}$ & $\begin{array}{l}1=\text { No description of corporate governance } \\
2=\text { Limited description of corporate governance } \\
3=\text { Sufficient description of corporate governance } \\
4=\text { Very much description of corporate governance } \\
5=\text { Very extensive description of corporate governance }\end{array}$ \\
\hline & $\begin{array}{l}\text { To what extent does the annual } \\
\text { report contain disclosure related to } \\
\text { both positive and negative } \\
\text { contingencies? }\end{array}$ & $\begin{array}{l}1=\text { No disclosure } \\
2=\text { Limited disclosure } \\
3=\text { Sufficient disclosure } \\
4=\text { Very much disclosure } \\
5=\text { Very extensive disclosure }\end{array}$ \\
\hline & $\begin{array}{l}\text { To what extent does the annual } \\
\text { report contain information } \\
\text { concerning bonuses of the board of } \\
\text { directors? }\end{array}$ & $\begin{array}{l}1=\text { No information concerning bonuses } \\
2=\text { Limited information concerning bonuses } \\
3=\text { Sufficient information concerning bonuses } \\
4=\text { Very much information concerning bonuses. } \\
5=\text { Very extensive information concerning bonuses }\end{array}$ \\
\hline \multirow{3}{*}{$\begin{array}{l}\text { Understand } \\
\text { ability }\end{array}$} & $\begin{array}{l}\text { To what extent is the annual report } \\
\text { presented in a well organized } \\
\text { manner? }\end{array}$ & $\begin{array}{l}1=\text { Very bad presentation } 2=\text { Bad presentation } \\
3=\text { Poor presentation } \\
4=\text { Good presentation } \\
5=\text { Very good presentation }\end{array}$ \\
\hline & $\begin{array}{l}\text { To what extent does the presence } \\
\text { of graphs and tables clarify the } \\
\text { presented information? }\end{array}$ & $\begin{array}{l}1=\text { No graphs and tables. } \\
2=1-5 \text { graphs } \\
3=6-10 \text { graphs } \\
4=11-15 \text { graphs } \\
5=>15 \text { graphs }\end{array}$ \\
\hline & $\begin{array}{l}\text { To what extent is the use of } \\
\text { language and technical jargon in }\end{array}$ & $\begin{array}{l}1=\text { Very much jargon } \\
2=\text { Much jargon }\end{array}$ \\
\hline
\end{tabular}




\begin{tabular}{|c|c|c|}
\hline & $\begin{array}{l}\text { the annual report easy } \\
\text { to follow? }\end{array}$ & $\begin{array}{l}3=\text { Moderate use of jargon } 4=\text { Limited use of jargon } \\
5=\text { No/hardly any jargon }\end{array}$ \\
\hline & What is the size of the glossary? & $\begin{array}{l}1=\text { No glossary } \\
2=\text { Less than } 1 \text { page } \\
3=\text { Approximately } 1 \text { page } 4=1-2 \text { pages } \\
5=>2 \text { pages }\end{array}$ \\
\hline & $\begin{array}{l}\text { To what extent does the annual } \\
\text { report contain information } \\
\text { concerning mission and strategy? }\end{array}$ & $\begin{array}{l}1=\text { No information concerning mission and strategy } \\
2=\text { Limited information concerning mission and strategy } \\
3=\text { Sufficient information concerning mission and } \\
\text { strategy } \\
4=\text { Very much information concerning mission and } \\
\text { strategy } \\
5=\text { Very extensive information concerning mission and } \\
\text { strategy }\end{array}$ \\
\hline & $\begin{array}{l}\text { To what extent is the annual report } \\
\text { understandable in the perception } \\
\text { of the researcher? }\end{array}$ & $\begin{array}{l}1=\text { Very badly understandable } \\
2=\text { Badly understandable } \\
3=\text { Poorly understandable } \\
4=\text { Good understandable } \\
5=\text { Very good understandable }\end{array}$ \\
\hline & $\begin{array}{l}\text { To what extent are the notes to the } \\
\text { balance sheet and the income } \\
\text { statement sufficiently clear? }\end{array}$ & $\begin{array}{l}1=\text { No explanation } \\
2=\text { Very short description, difficult to understand } \\
3=\text { Explanation that describes what happens } \\
4=\text { Terms are explained (which assumptions etc.) } \\
5=\text { Everything that might be difficult to understand is } \\
\text { explained }\end{array}$ \\
\hline \multirow{6}{*}{$\begin{array}{l}\text { Comparabil } \\
\text { ity }\end{array}$} & $\begin{array}{l}\text { To what extent are changes in } \\
\text { accounting policies disclosed? }\end{array}$ & $\begin{array}{l}1=\text { No disclosure } \\
2=\text { Limited disclosure } \\
3=\text { Sufficient disclosure } \\
4=\text { Very much disclosure } \\
5=\text { Very extensive disclosure }\end{array}$ \\
\hline & $\begin{array}{l}\text { To what extent are changes in } \\
\text { accounting estimates disclosed? }\end{array}$ & $\begin{array}{l}1=\text { No disclosure } \\
2=\text { Limited disclosure } \\
3=\text { Sufficient disclosure } \\
4=\text { Very much disclosure } \\
5=\text { Very extensive disclosure }\end{array}$ \\
\hline & $\begin{array}{l}\text { To what extent does the company } \\
\text { provide a comparison of the results } \\
\text { of current accounting period with } \\
\text { previous accounting periods? }\end{array}$ & $\begin{array}{l}1=\text { No comparison } \\
2=\text { Only with previous year } \\
3=\text { With 5years } \\
4=5 \text { years }+ \text { description of implications } \\
5=10 \text { years }+ \text { description of implications }\end{array}$ \\
\hline & $\begin{array}{l}\text { To what extent does the company } \\
\text { present financial index numbers } \\
\text { and ratios in the annual report? }\end{array}$ & $\begin{array}{l}1=\text { No ratios } \\
2=1-5 \text { ratios } \\
3=6-10 \text { ratios } \\
4=11-15 \text { ratios } \\
5=>15 \text { ratios }\end{array}$ \\
\hline & $\begin{array}{l}\text { To what extent does the annual } \\
\text { report contain information } \\
\text { concerning companies' shares? }\end{array}$ & $\begin{array}{l}1=\text { No information concerning companies' shares } \\
2=\text { Limited information concerning companies' shares } \\
3=\text { Sufficient information concerning companies' shares } \\
4=\text { Very much information concerning companies' } \\
\text { shares } \\
5=\text { Very extensive information concerning companies' } \\
\text { shares }\end{array}$ \\
\hline & $\begin{array}{l}\text { To what extent did the company } \\
\text { adjust previous accounting } \\
\text { period's figures, for the effect of } \\
\text { the implementation of a change in } \\
\text { accounting policy or revisions in } \\
\text { accounting estimates? }\end{array}$ & $\begin{array}{l}1=\text { No adjustments } \\
2=\text { Described adjustments } \\
3=\text { Actual adjustments (one year) } \\
4=2 \text { years } \\
5=>2 \text { years+notes }\end{array}$ \\
\hline
\end{tabular}




\begin{tabular}{|l|l|l|}
\multirow{3}{*}{ Timeliness } & Natural logarithm of amount of days \\
& How many days did it take for the & $1=1-1.99$ \\
& auditor to sign the auditors' report & $2-2.99$ \\
& after book year end? & $3=3-3.99$ \\
& & $4=4-4.99$ \\
& $5=5-5.99$ \\
\hline
\end{tabular}




\section{Appendix C: Variables measurement and definition}

\begin{tabular}{|c|c|}
\hline Symbol & Definition \\
\hline EM_LLP & represents the extent of earnings management \\
\hline QVD & stands for the quality of voluntary disclosure \\
\hline I_BD & is calculated as the total number of independent directors scaled by the total number of board directors \\
\hline BD_EX & represents the proportion of board directors with financial expertise \\
\hline D_U & is a dummy variable that takes a score of one if the Chief Executive Officer (CEO) has more than one role and zero otherwise \\
\hline B_GD & represents the proportion of women board directors \\
\hline A_CZ & represents the size of the audit committee \\
\hline A_CM & stands for the total number of audit committee meeting held in a financial year \\
\hline A_CEX & represents the audit members with financial expertise \\
\hline Big_4 & is a dummy variable the takes the value of one if the largest four auditing firms audit the bank and zero otherwise. \\
\hline A_CG & stands for the proportion of audit committee female members \\
\hline M_OS & is the proportion of total shares held by managers scaled by the total number of outstanding shares \\
\hline P_ROF & is calculated as net income scaled by the lag of total assets \\
\hline L_IQ & is measured as current assets scaled by current liabilities \\
\hline CR & is the credit risk and measured as the ratio of loan loss provisions scaled by total loans \\
\hline CAP & $\begin{array}{l}\text { represents capital adequacy ratio and is measured as the proportion of actual regulatory capital (Tier } 1 \text { capital) divided by the total } \\
\text { assets }\end{array}$ \\
\hline L-D & stands for external financing is measured as loan to deposit for bank $i$ at the year $t$ \\
\hline PT & is a dummy variable that takes the value of one if a bank is based in Egypt, Yemen, Syria, Tunisia, or Iraq and zero otherwise. \\
\hline GCC & is a dummy variable that takes a value of one if a bank is based in GCC and zero otherwise. \\
\hline
\end{tabular}

